\title{
Reproduction and fertility in the mink (Mustela vison)
}

\author{
C. Sundqvist, A. G. Amador and A. Bartke \\ Department of Physiology, School of Medicine, Southern Illinois University, Carbondale, \\ IL 62901-6512, USA
}

Introduction

Page

The hypothalamus, pituitary and pineal

413

The hypothalamic-pituitary unit

414

Anatomy

414

Secretion of hormones

414

The pineal gland

414

Anatomy and secretion of hormones

Reproductive biology of the female $\quad 416$

Oogenesis and ovulation $\quad 416$

$\begin{array}{ll}\text { The phenomenon of delayed implantation } & 419\end{array}$

Fertilization, gestation and parturition 421

Other studies on the reproductive biology of the female $\quad 422$

Reproductive biology of the male $\quad 422$

Testicular development and spermatogenesis $\quad 422$

$\begin{array}{lr}\text { Photoperiodic regulation of male reproduction } & 425\end{array}$

Other aspects of male reproductive biology $\quad 426$

$\begin{array}{ll}\text { Reproductive problems in the female } & 427\end{array}$

Reproductive problems in the male $\quad 429$

References 431

Keywords: $\operatorname{mink}$; reproduction; fertility; seasonal breeder; review

\section{Introduction}

The mink (Mustela vison) is a seasonally breeding, semi-aquatic animal belonging to the mammalian order Carnivora. It is not a traditional laboratory animal, but nevertheless of great importance because it is a valuable fur-bearing animal bred in captivity since the beginning of this century. There are only a few reviews on reproduction in the mink (Hansson, 1947; Enders, 1952; Venge, 1973; Sundqvist et al., 1988) and, despite a considerably large body of information about this species, there have recently been even fewer efforts to gather the accumulated knowledge on reproduction. Some books or book chapters have been written to satisfy the practical farmer (Hodgson, 1945; Kellogg et al., 1948; Gunn, 1949; Hodgson, 1958; Jørgensen, 1985; Dunstone, 1986; Tomson, 1987), but mostly the content of the book chapters does not deliver the information the scientist is looking for. Many investigators might not be aware of the information available about this animal. This review will, therefore, focus the reader's attention on current knowledge of mink reproduction and fertility employing a more scientific approach. Comparisons of reproduction in traditional laboratory animals with that of the mink will be made when appropriate, and several suggestions for further studies are proposed. 
References have been extracted from large databases (mainly BIOSIS and MEDLINE), and contacts with several scientists have made it possible to gather information and articles otherwise not easy to find. The total number of scientific research papers on mink that we were able to locate in the fall of 1988 was 4650 and $16 \%$ of these papers dealt with reproduction.

The reader will be guided briefly through the reproductive processes for which great differences are not found between the mink and other mammals. More detailed descriptions are provided for those processes for which differences are important or for which there is current active research.

\section{The hypothalamus, pituitary and pineal}

\section{The hypothalamic-pituitary unit}

\section{Anatomy}

In the mink, as in other mammals, the hypothalamus and the pituitary gland form a close anatomical and functional unit in which the hypothalamus has the dominant role (see Fig. 1: Pilleri, 1960; Kruska, 1977; Drekic et al., 1981). It is $7.8 \mathrm{~mm}$ long and is part of the base of the brain. Furthermore it forms the lateral wall of the lower part of the third ventricle. The anterior hypothalamus embraces the supraoptic area which lies rostral to the optic chiasma. The posterior hypothalamus includes the mamillary complex. The central portion of the infundibulum or median eminence is enveloped from below by the pars tuberalis (Ribas, 1973) of the anterior pituitary, and is penetrated by many capillary loops from the plexus of the hypophysial portal circulation. This neurovascular complex is the site for the release of several peptides and neurotransmitters. In the mink the median eminence is described as being substantially larger $(1.2-1.5 \mathrm{mg}$ wet weight) than that of other animals of comparable size (Knigge \& Silverman, 1971; Silverman et al., 1972).

The pituitary is connected with the hypothalamus by the pituitary stalk (Fig. 1). The most characteristic feature of the mink pituitary is the presence of a double intermediate lobe (Weman, 1970; Weman \& Nobin, 1973). The gland is composed of the adenohypophysis and the neurohypophysis. The latter forms the infundibular stem, which begins at the median eminence and ends as the infundibular process. The adenohypophysis consists of pars distalis and pars tuberalis (Weman, 1970, 1974a, b).

\section{Secretion of hormones}

The hypothalamus contains groups of neurosecretory cells with endocrine activity and secretes releasing factors which influence the function of the anterior lobe of the pituitary gland. Several hormones are secreted but those hypothalamic hormones that play a primary role in reproduction are luteinizing hormone-releasing hormone (LHRH), dopamine, and oxytocin. The median eminence is metabolically very active. There is a rapid transport of the neutral and non-metabolizable amino acid $\alpha$-aminoisobutyric acid and thyroxine from the cerebrospinal fluid to pituitary portal vessels (Silverman et al., 1972; Silverman \& Knigge, 1972, 1973). The median eminence appears to possess a potential mechanism for regulating the level of free thyroxine that reaches the pituitary (Silverman \& Knigge, 1972). Additionally, the median eminence was found to take up LHRH rapidly. Oestradiol and testosterone, but not corticosterone, inhibit this uptake (Vaala \& Knigge, 1974). Cyclic adenosine monophosphate (cAMP) has been found in the mink median eminence. The neurotransmitters noradrenaline and dopamine are able to alter the levels of cAMP (Donofrio, 1974). This could mean that at least some neuroendocrine processes at the level of the median eminence are mediated via changes in cAMP titres in nerve terminals and ependymal cells.

In the mink, two different types of gonadotrophs have been described (Weman, 1974a; Murphy \& James, 1976; Busch, 1976) and this might speak in favour of two different releasing factors or mechanisms for luteinizing hormone (LH) and follicle-stimulating hormone (FSH) release. 


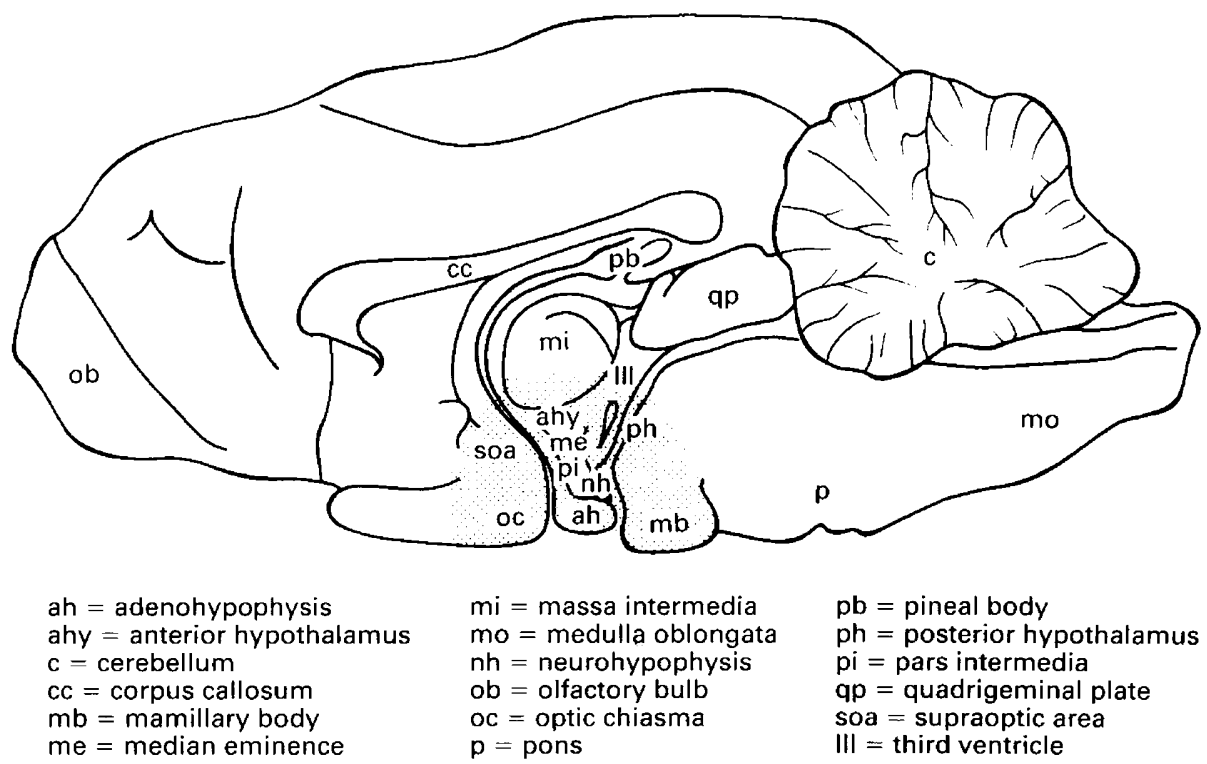

Fig. 1. Schematic representation of the mink brain. The brain weighs approximately $15 \mathrm{~g}$ in the adult male mink and its most characteristic features are a large median eminence, a double intermediate lobe of the pituitary gland and a pineal gland connected to the roof of the third ventricle by a stalk.

Peripheral gonadotrophs presumably produce FSH while the central ones produce LH (Weman, 1970). However, because of the paucity of pertinent information there is little reason to reject or accept the widely accepted concept of LHRH being the primary hypothalamic peptide that regulates both $\mathrm{LH}$ and $\mathrm{FSH}$ secretion. Studies on the intriguing possibility of dual regulation of the gonadotrophins in the mink are required.

Pituitary prolactin release in the mink appears to be under dopaminergic inhibitory control as it is in other mammals. The dopamine agonist, bromocriptine, is effective in delaying the preimplantation rise of prolactin and progesterone while opposite effects were evident after administration of prolactin (Papke et al., 1980; Martinet et al., 1981a, b; Murphy et al., 1981). On the other hand prolactin secretion can be stimulated with pimozide, a dopamine antagonist (Murphy, 1983b). The main function of prolactin in the female is the stimulation of milk synthesis in the mammary gland. Indeed, large numbers of lactotrophs are found in the anterior pituitary of lactating mink (Murphy \& James, 1976). Prolactin also plays an important role in the control of luteal function and in the termination of delayed implantation, which is a typical feature of this species (Hansson, 1947; Busch, 1976). This effect of prolactin is discussed in more detail later.

Oxytocin seems to be synthesized in both the supraoptic and paraventricular nuclei, and is thereafter packaged in secretory granules and stored in the posterior pituitary. The stimulus of suckling initiates the release of oxytoxin which stimulates expulsion of milk from the nipples (Conant, 1962). If parturition is abnormally prolonged, uterine contractions can be intensified by injecting a small dose of oxytocin (Jørgensen, 1985). The role of oxytocin in the male mink is unclear, since only one study on the stimulation of capsular contraction has been done (Ellis et al., 1981b).

In the female mink, $\mathrm{LH}$ induces ovulation and stimulates the secretion of oestrogens in the ovarian theca interna cells (Venge, 1973). FSH promotes the proliferation of granulosa cells and the growth of Graafian follicles in the ovary. The size of the ovum is independent of FSH. The granulosa cells shelter the ovum and act as precursors of the luteal cells. In the male mink, LH stimulates steroidogenesis in the Leydig cells, and FSH and androgens are responsible for the stimulation of spermatogenesis (Jørgensen, 1985). Interestingly, plasma concentrations of 
$\alpha$-melanocyte-stimulating hormone are inversely related to plasma testosterone values and testicular development (Ellis et al., 1982b).

Oestrogen-concentrating cells in the mink brain are almost solely distributed in the hypothalamus and the limbic system (Morrell et al., 1977), which is in agreement with similar studies in the hamster (Krieger et al., 1977). These oestrogen-concentrating cells are important in establishing the feedback relationships between gonads and the brain. No seasonal effect on the number of brain oestrogen-concentrating cells has been found (Morrell et al., 1977), although short photoperiod has been shown to affect the hypothalamic-pituitary neurosecretory system (Yurisova \& Klochkov, 1978; Yurisova et al., 1980). Possible worthwhile topics for future studies should include functional significance of sex steroid-concentrating cells in the brain and the relationship of CNS steroid binding to the sensitivity of the brain to extrinsic hormonal influences during critical periods of early post-natal development and seasonal transitions between reproductive activity and quiescence.

\section{The pineal gland}

\section{Anatomy and secretion of hormones}

In the mink as in many mammalian species, the pineal gland mediates the effects of photoperiod on many physiological functions including reproductive activity (Reiter, 1974; Ellis et al., 1982b; Martinet \& Allain, 1985; Ravault et al., 1986). The pineal is an elongated gland connected rostrally to the posterior end of the roof of the third ventricle (Fig. 1) (Weman \& Nobin, 1979; Rouvet, 1982). Unlike the situation in the ferret (David \& Herbert, 1973), in the mink there is a stalk connecting the pineal to the brain (Rouvet, 1982). According to Rouvet (1982) the pineal is composed of secretory cells called pinealocytes. These cells can have either light or dark cytoplasm and the dark ones have been found to contain more free ribosomes and less rough endoplasmic reticulum (Rouvet, 1982).

The pineal synthesizes several indoleamines of which melatonin has the most pronounced effects on reproduction. When melatonin is given to the male mink in the summer in order to produce earlier development of the winter coat there is either stimulation (Allain et al., 1981; Valtonen et al., 1986) or inhibition (Ellis, 1985) of testicular development. In the female, the pineal is involved in the regulation of the photo-dependent termination of the embryonic diapause which will be discussed later (Murphy \& James, 1974a). Removal of the pineal renders the mink unresponsive to the stimulatory effects of artificial long days on prolactin and progesterone secretion during pregnancy (Martinet et al., 1981a, 1985; Murphy et al., 1981).

\section{Reproductive biology of the female}

\section{Oogenesis and ovulation}

The ovaries of the mink are bean-shaped, located opposite to the caudal portion of the kidneys and surrounded almost completely by the ovarian bursa (Fig. 2). Their size varies at different periods, being small $(0.30 \mathrm{~g})$ during the long anoestrum, increasing in size as the breeding season approaches $(0.60 \mathrm{~g})$ and reaching maximum size about 2 weeks before parturition $(0.65 \mathrm{~g})$ (Fig. 3) (Hansson, 1947; Enders, 1952; Venge, 1973; Pilbeam et al., 1979). The amount of sunlight plays an active role in accelerating oestrus and ovarian growth (Stevenson, 1946; Hansson, 1947; Hammond, 1951a) although breeding may commence even if complete darkness is maintained from the end of December to May (Kirk, 1962). No systematic study on the prenatal development of the gonadal system could be found, but Kissen \& Price (1962) point out that the mink in general appears to develop in utero in a typical mammalian fashion.

The ovary consists of an outer zone (cortex) and an inner zone (medulla). In May, the medulla in the newborn mink consists of loose connective tissue, and is not yet well differentiated from the 


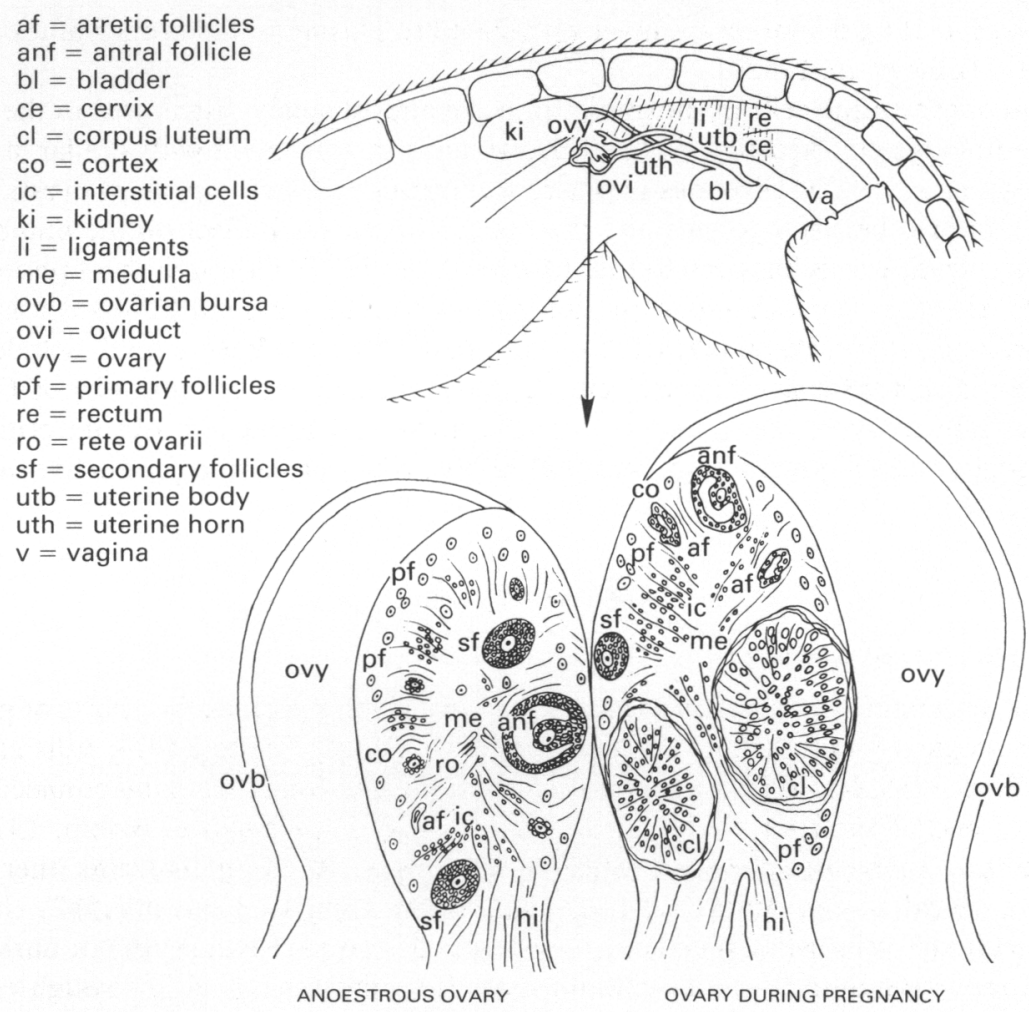

Fig. 2. The mink is a seasonally breeding animal with the size of the ovaries varying at different periods of the year. The ovaries are small during the long period of anoestrus (May-February) and increase in size as the mating season (March) approaches. The diagram shows the typical features of an ovary during anoestrus and pregnancy. One remarkable feature is that the corpora lutea are not initially producing sufficient amounts of progesterone for implantation. This phenomenon allows a 2 nd or $3 \mathrm{rd}$ oestrus and the ovulation of a new set of eggs during the short mating season.

cortex, which has a few gonocytes (Enders, 1952). In the adult, there is a clear demarcation between the two zones (Hansson, 1947). A few oogonial cells (primordial germ cells) and primary oocytes can be found scattered through the ovarian cortex of the 4-day-old mink. The first interstitial cells begin to develop from cells of sterile sex cords in the medullar zone by Day 6 (Zaleska-Freljan, 1976). The rudimentary rete ovarii has, during that time, also grown into the interior of the gonad from the hilar side (Byskov, 1975; Zaleska-Freljan, 1976). It is speculated that the rete system interacts with the cortex, initiating meiosis, and furthermore, that the rete cells as well as cells of the surface epithelium contribute to the granulosa cell layer (Byskov, 1975). All germ cells have entered meiotic prophase by 2 weeks post partum (Byskov, 1975). In the medulla, follicle formation has progressed and many of the growing follicles are inter-connected by broad cell cords. Hansson (1947) gives a full description of the follicular development in the mink and he distinguishes between 9 different follicular stages.

In the 6-week-old mink (middle of June), primordial follicles accumulate, Graafian follicles appear, and occasional follicles near the interstitial tissue degenerate, as the cortex of the ovary develops. Two distinct layers can be seen in the medulla: the external layer consisting of aggregations of interstitial cells containing lipids, and the internal layer of connective tissue in the centre of which the rete ovarii can be seen.

In December, single primordial follicles, surrounded by a single layer of follicular cells, are observed in the outer part of the cortex. In the inner parts of the cortex, growing oocytes 


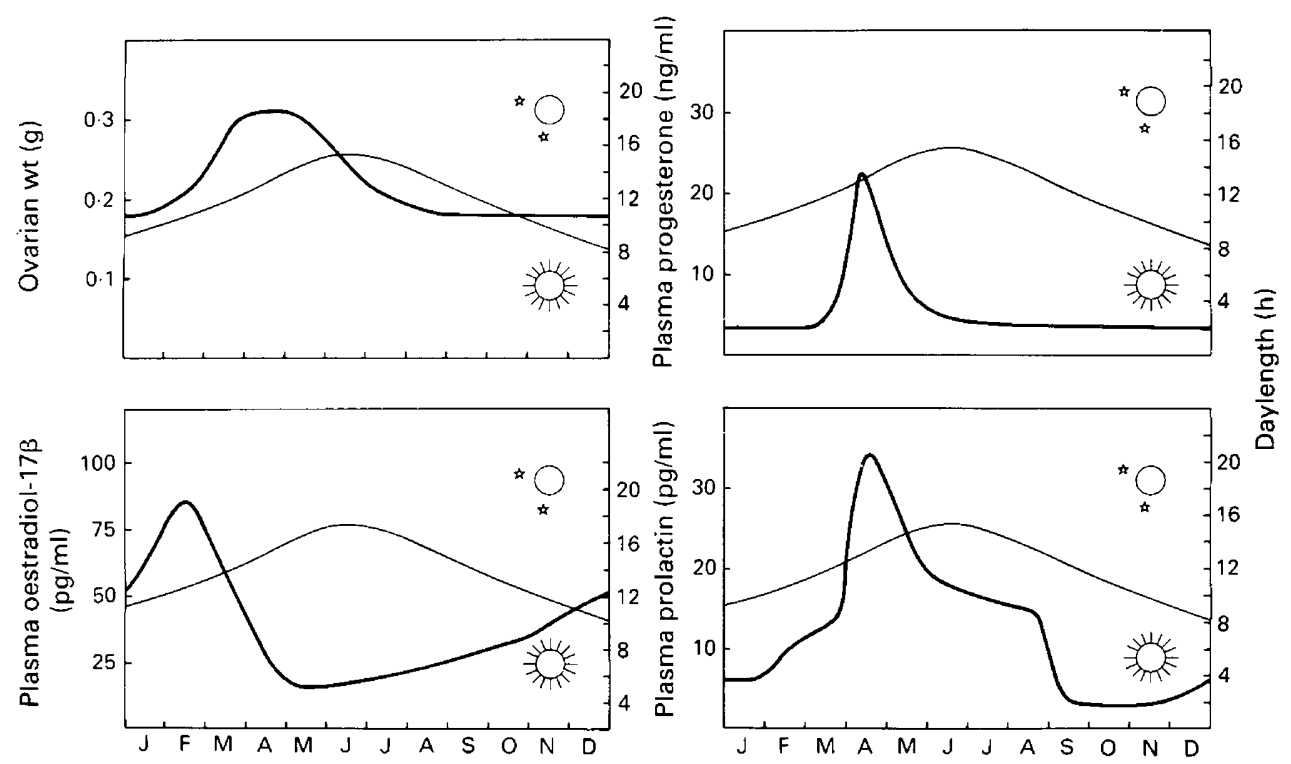

Fig. 3. Reproductive characteristics of the female mink as a function of the annual light-dark cycle.

surrounded by zona pellucida are found. Follicular growth can be stimulated with 100 i.u. pregnant mares' serum gonadotrophin (PMSG) (Hammond, 1952). Ovarian and follicular growth can be stimulated during the anoestrous period with megoestrol acetate (Nosova, 1978). During oogenesis, as many as 100 nucleolus-like bodies develop per nucleus (Kidnadze et al., 1980). Formation of a second generation of interstitial cells, developed from the theca interna of atretic follicles, is observed for the first time in December (Zaleska-Freljan, 1976) and there is a marked development of the interstitial tissue as the breeding season nears. The interstitial gland cells are typical steroidsecreting cells (Møller, 1973a, c). Interestingly, it is not possible to detect any changes in the interstitial cells during different times of the year, contrary to what is observed in the stoat, another mustelid (Gulamhusein \& Thawley, 1972).

Mink mate, as a rule, during the month of March both in the wild and in farm conditions (Venge, 1973; Chanin, 1983). During this period, 4 or more waves of follicles mature at approximately 8-day intervals (Enders, 1952). Once follicles reach maturity, LH stimulates ovulation. As a result of ovulation one or more corpora lutea occur in the cortex of the ovary in April (Hansson, 1947; Abramov, 1960; Danilov \& Tumanov, 1975). The mink is an induced ovulator and ovulation occurs about $48 \mathrm{~h}$ (range 28-72 h) after mating (Hansson, 1947; Nosova, 1977c; Adams, 1981). Ovulation was reported to occur 35-40 h after the injection of 50-200 i.u. hCG (Hammond, 1952; Chang, 1968) but may also result from only a brief contact with a male, not necessarily involving seizure or intromission (Enders, 1952). Paradoxically, true corpora lutea form in unmated females removed from the vicinity of males some months before the breeding season (Møller, 1974). This suggests that spontaneous ovulation might occur in the mink. Promising results were obtained using PMSG, LHRH and hCG to induce oestrus or ovulation (Konrad et al., 1972; Murphy, 1976; Hattenhauer, 1984; Hattenhauer et al., 1984; Hattenhauer \& Pötschulat, 1984; Jarosz et al., 1987). Greater levels of stimulation were needed for the induction of ovulation in already mated mink (Adams, 1981). On some mink farms, hCG (Rietveld, 1978; Adams 1981; Bernatskii \& Polyntsev, 1982) or a vasectomized male (Bernatskii, 1971; Adams \& Rietveld, 1981) are used to induce the first ovulation during the breeding season. Remating the female the next day with a male of known fertility ensures a good litter size.

The ovulated egg is surrounded by a thin zona pellucida (Enders, 1938). Histological studies show that 5 or possibly 6 stages of corpus luteum development can be distinguished (Hansson, 
1947). The delayed functioning of the corpora lutea is rather peculiar in the mink, and this will be discussed in more detail in relation to the phenomenon of delayed implantation (see below). The presence of corpora lutea does not immediately suppress the formation of primary follicles (Venge, 1973). Administration of megoestrol acetate during the oestrous cycle reduces the number of ovulating follicles (Nosova, 1977a). Normally, a slight tendency towards an optimum in the number of rupturing follicles may be seen 7-10 days after a previous ovulation, and more follicles rupture in the middle than at the beginning or the end of the mating season (Hansson, 1947). A Graafian follicle that is ready for ovulation attains an average diameter of 1.0-1.1 mm. Luteinizing hormone has been successfully assayed in the mink (Murphy, 1979a; Mondain-Monval et al., 1985) but it has not been possible to measure FSH concentrations. We feel that better knowledge of the control of oogenesis in the mink could be obtained if it were possible to measure FSH concentrations. Although several articles deal with the anatomy and function of the mink ovary, there seems to be a considerable lack of accurate quantitative data on oogenesis. For comparative purposes it would, for example, be interesting to know how many primary follicles exist in the ovary and the frequency with which the follicles become atretic during ovarian development.

The mink is able to ovulate several times during the same mating season. If the female is fertilized during the first mating, she may still ovulate 8-10 days later, and thereafter may give birth to kits from two different ovulations (a phenomenon called superfetation) (Johansson \& Venge, 1951; Enders, 1952; Shackelford, 1952). Many different mating schedules utilizing the phenomenon of repeated ovulations during the breeding season have been applied to the mink (Johansson \& Venge, 1951; Enders, 1952; Shackelford, 1952; Lecht \& Reck, 1957; Friend \& Crampton, 1960; Johansson, 1965b; Narucka, 1973; Maciejowski et al., 1973; Kukla, 1975; Fiedler et al., 1975; Rebreanu et al., 1981a; Stolc et al., 1984). The generally accepted protocol to achieve the best results requires that early in the breeding season, mink be remated 7-8 days after the first mating, and that later in the season, they be remated the day after the first mating (Venge, 1973; Jørgensen, 1985). To increase productivity hormonal therapy has been used with variable results (Venge, 1956b; Franklin, 1958; Cochrane \& Shackelford, 1962; Murphy, 1976, 1979a; Hattenhauer, 1984; Hattenhauer et al., 1984; Hattenhauer \& Pötschulat, 1984). Surprisingly, a $0.5 \mathrm{ml}$ dose of the supermutagen 1,4-bis-diazoacetylbutane deposited inside the vagina in a concentration of 1:500 increased the litter-size compared to controls (Bernatskii et al., 1977).

The structure of the corpus luteum has been extensively studied and it was found that mink lutein cells are active, secreting progesterone during pregnancy (Venge, 1959; Enders, 1962; Enders \& Enders, 1963; Miladinovic, 1969; Møller, 1973c; Kolpovskii, 1978; Muresan et al., 1984). The mink is, however, different from most other species in that corpora lutea do not initially produce high quantities of progesterone (Canivenc \& Bonnin-Laffargue, 1967). This low level of progesterone allows a second oestrus, and the ovulation of a second set of eggs capable of normal development (Bernatskii \& Diveeva, 1981). However, there is indication that ova fertilized after the last ovulation develop more often than ova from previous ovulations (Enders, 1949). Only partial luteinization of the granulosa cells of ovulated follicles occurs before implantation (Enders, 1960). There is a considerable variation in the mean numbers of corpora lutea in different types of mink, e.g. $19 \cdot 2,17 \cdot 2,18.3$ and 15.8 in the dark, pastel, pearl and silverblue colour phases respectively (Adams, 1973). At the end of the breeding season the primary and secondary follicles regress and the formation of new follicles is kept at a minimum until the end of the anoestrous period (Kolpovskii, 1979). In non-pregnant females the corpora lutea regress after the middle of April (Kolpovskii, 1983).

\section{The phenomenon of delayed implantation}

One remarkable feature in mink reproduction, is that the fertilized egg undergoes partial development (to the blastula stage) and thereafter remains inactive until it is implanted in the uterus (Hansson, 1947; Enders, 1952). The mink is by no means unique in this aspect, but successful 
breeding of the mink in farm conditions was greatly enhanced when it was detected that the mink experiences an obligate arrest of implantation. This also makes it possible to give a proper explanation of the great variability in pregnancy lengths. There is a large amount of information about delayed implantation in this species. The mink embryo develops from zygote into a blastocyst by the 8th day post coitum (Hansson, 1947). During this period the trophoblast is formed, ensuring nutrients for the blastocyst. As a result of the embryonic diapause, the embryo may remain in the blastocyst stage for up to 49 days post coitum. The blastocyst divides $7-8$ times, and consists thereafter of a maximum of 300 cells (Enders, 1952). In culture, the trophoblast soon shrinks away from the zona pellucida, but the blastocysts survive for as long as 5 months (Enders \& Pearson, 1946). However, they do not grow, regardless of the use of sophisticated culture techniques (Daniel, 1967; Gulyas et al., 1969). In the case of the mink, delayed implantation persists only for weeks, rather than months, as in other members of the mustelid family (Mead, 1981). Development of the embryo is resumed when the maternal environment allows implantation (Baevsky, 1963; Vagin, 1983).

The length of embryonic quiescence may vary and the exact mechanism by which the dormant embryo becomes reactivated is not thoroughly understood. The morphological signs of the completion of diapause are the disappearance of the zona pellucida, the release of the trophoblast, and the growth of fragments of transverse folds on the endometrium (Hansson, 1947). There is ample evidence for photoperiodic control of egg implantation (Murphy \& James, 1974a; Allais \& Martinet, 1978; Travis \& Pilbeam, 1980). The pineal might play a major role in the control of implantation because denervation of the pineal by cervical ganglionectomy inhibits the induction of implantation in mink stimulated by long photoperiod (Murphy \& James, 1974a), and eliminates the diurnal variation of serum melatonin (Ravault et al., 1986) while administration of melatonin delays the preimplantation rise in plasma progesterone (Duby et al., 1972). It has been shown that whenever the mink is mated during the breeding season, implantation always occurs at the beginning of April (near the vernal equinox) (Enders, 1952; Baevsky, 1961). Histologically, implantation does not occur until at least 20 days after mating (Abramov, 1960). This means that the gestation period becomes very long if the mink is mated early in March compared with matings in late March (Hansson, 1947). Implantation follows the initial increase in progesterone by 5-10 days (Møller, 1973b; Murphy \& Moger, 1977; Pilbeam et al., 1979). An artificial increase in photoperiod after mating reduces the gestation period (Holcomb et al., 1962; Belyaev et al., 1963; Aulerich et al., 1963). In one study, however, a lengthened photoperiod after mating did not affect pregnancy length (Murphy, 1977). The time of breeding in mink can be moved forward by exposing them to additional light before the mating season (Holcomb et al., 1962) by hastening the onset of prolactin and progesterone secretion (Allais \& Martinet, 1978; Martinet et al., 1981b). The duration of pregnancy in the mink is very variable (Svihla, 1931; Bowness, 1942; Pearson \& Enders, 1944; Hansson, 1947; Enders, 1952; Bowness, 1968) and the date of mating is the most important factor accounting for this great variability (Hansson, 1947). Matings late in the breeding season tend to shorten the gestation period. The mean length of pregnancy is approximately 51 days (Bowness, 1942; Pearson \& Enders, 1944; Stevenson, 1945; Enders, 1952; Venge, 1966, 1973; Dukelow, 1966; Bernatskii, 1983). Short photoperiods, or injection of melatonin, inhibit prolactin secretion (Martinet et al., 1983). Therefore, increasing daylength in the spring is the cue that elicits sufficient prolactin secretion, leading to the termination of embryonic diapause (Fig. 3). It appears that $5 \alpha$-pregnane-3,20-dione is the predominant steroid to which uterine progesterone is converted (Rose et al., 1983b).

Murphy et al. $(1982,1983)$ showed the importance of ovarian factors in implantation by demonstrating that ovariectomy during embryonic quiescence consistently prevents implantation. Exogenous progesterone or medroxyprogesterone acetate failed to correct the situation and pregnancies could not be shortened by this treatment (Hansson, 1947; Hammon, 1951b; Holcomb, 1967; Murphy et al., 1982, 1983; Murphy, 1983a; Christiansen, 1985). Contrary to these findings, some investigators (Concannon et al., 1980; Jarosz \& Dukelow, 1985) found evidence that medroxyprogesterone could advance the time of implantation. 
There is now evidence that prolactin is the major component of the luteotrophic complex that terminates embryonic diapause in the mink by initiating luteal progesterone secretion (Papke et al., 1980; Murphy et al., 1980; Martinet et al., 1981a). If the mink is treated with prolactin during the embryonic diapause there is an increase in progesterone production (Papke et al., 1980; Martinet et al., 1981a, b). An opposite effect on progesterone secretion can be obtained by administering melatonin (Martinet et al., 1981b). Furthermore, Murphy et al. (1981) showed that, in hypophysectomized mink, prolactin injections alone could activate the corpora lutea and stimulate implantation. By repeated administration of LHRH antiserum, Murphy et al. (1984) showed that pituitary release of LH is essential for luteal maintenance in the mink. Other mustelids also require an intact hypophysis for normal luteal function and embryo implantation (Mead, 1975; Murphy, 1979b). Canivenc et al. (1966) suggested that the uterus is required in pregnant females for normal luteal function, but Duby et al. (1972) failed to support this finding. Additional evidence for the importance of prolactin in the regulation of ovarian function in the mink is given by Rose $e t$ al. (1983a, 1986) who showed that prolactin receptors were present in the ovaries and the uterus. There is a reduction in the numbers of receptors during blastocyst reactivation, probably due to the occupancy of those receptor sites by endogenous prolactin.

\section{Fertilization, gestation and parturition}

In the oviduct an environment is provided that allows sperm capacitation, fertilization and early embryonic development (Hansson, 1947; Enders, 1952). The oviduct is firmly attached to the ovarian capsule and it is said to be $\sim 30 \mathrm{~mm}$ (Enders, 1952) or 10-15 mm (Hansson, 1947) long. As in most other mammals, the lining of the lumen of the oviduct is greatly folded. When oestrus approaches, the oviduct increases in size and the folds become more rounded. Cilia are present throughout the oviduct but are reduced in number near the uterus (Enders, 1952). Ciliary activity and co-ordinated muscular contractions regulate the rate at which spermatozoa move to the fertilization site and eggs are transported to the uterus. There is some indirect evidence that the ovulated eggs travel through the oviduct in 6 days (Hansson, 1947). Fertilization takes place in the bursa ovarii or within the fimbriated portion of the oviduct (Enders, 1952). The fertilized ova measure $135-151 \mu \mathrm{m}$ in diameter, whereas the cytoplasm measures $103-110 \mu \mathrm{m}$ and the thickness of the zona pellucida is $11 \mu \mathrm{m}$ (Enders, 1938).

The bicornuate uterus of the mink is $\sim 30 \mathrm{~mm}$ long during the breeding season but the size changes dramatically throughout the year (Enders, 1952). Two different layers can be recognized: the endometrium and the myometrium. The former is composed of an epithelial lining of the uterine lumen and is filled with several endometrial glands (Enders et al., 1963). The gland cells undergo greater alterations during the season than the epithelial cells, which are characterized by large amounts of glycogen and smaller amounts of lipids, especially during the implantation phase (Enders, 1961; Enders et al., 1963; Hedlund et al., 1972). An increase in endometrial mucopolysaccharides is observed when implantation takes place (Murphy \& James, 1974b). After implantation, a zonodiscoidal (Hansson, 1947) or truly zonal (Enders, 1957) placenta is formed. The myometrium is greatly thickened during oestrus (Hansson, 1947).

Length of pregnancy (mean $=51$ days) is affected by delayed implantation, colour variety, photoperiod, age of female, mating frequency, and ambient temperature (Holcomb et al., 1962; Bura et al., 1981; Rebreanu et al., 1981b).

In the pregnant mink, basal plasma progesterone concentrations of $8 \mathrm{ng} / \mathrm{ml}$ show a gradual increase beginning about 40 days before parturition (Fig. 3) (Møller, 1973b; Allais \& Martinet, 1978; Pilbeam et al., 1979; Petrova et al., 1983; Einarsson, 1985). During this time the fertilized egg is still in the blastocyst stage. Maximum concentrations are observed 10-25 days later (early April) when the delayed implantation ends. After that, plasma progesterone concentrations decline gradually, and low levels are observed at parturition. Ovariectomy during pregnancy causes an abrupt fall in peripheral plasma progesterone concentrations (Møller, 1974). An obligatory 
relationship seems to exist between luteal function and the maintenance of pregnancy, since ovariectomy terminates pregnancy. Oestrogen concentrations remain low throughout pregnancy (Pilbeam et al., 1979). A pregnancy-associated serum protein has been isolated in the mink (Larsen et al., 1971).

Parturition occurs usually from the last week in April to the middle of May (Venge, 1973) and an average of 5 kits are born. Litters as large as 17 have been reported but litters of 10 or more are infrequent (Enders, 1952).

\section{Other studies on the reproductive biology of the female}

The cervix is a muscular sphincter which is situated at the posterior end of the uterus. It is closed at all times except during oestrus and parturition, when it relaxes enough to permit the passage of spermatozoa and fetuses respectively (Enders, 1952). When electrical stimulation of the cervix is used instead of a first mating, poor reproductive success is obtained (Murphy, 1979a). This would suggest that natural matings, or hormonal treatment causing ovulation, are necessary for good reproductive results in the mink. The plant derivative 6-methoxybenzoxazolinone, which stimulates reproductive function in voles, has no effect in the mink (Ginther et al., 1985).

The vagina of the mink is quite long ( $34 \mathrm{~mm}$ on average), distensible and muscular, having a tendency to lengthen further when oestrus approaches (Enders, 1952; Tihonov, 1963). It is not easy to classify the various phases of oestrus in the mink based on vaginal smears (Hansson, 1947; Enders, 1952). During oestrus the vagina contains a multilayered or partly keratinized and stratified squamous epithelium, presumably to protect against mechanical damage during copulation (Busch et al., 1979). Size of the vulva increases greatly during the breeding season, and treatment in November with PMSG causes a slight increase in vulvar size and uterine growth is stimulated (4-5 months before the breeding season) (Enders, 1952; Bernatskii \& Nosonova, 1968). A better response to PMSG is seen immediately after the breeding season than during anoestrus (Hartsough, 1942). The developmental stages of the external genitalia have been classified into 3 or 4 categories (Travis et al., 1978). Ovariectomized animals receiving diethylstilboestrol did not develop vulvar size large enough to permit intromission although they exhibited clear willingness to mate (Enders, 1948). Although vaginal smears can be useful to predict when the female will not mate, they cannot be used to predict the opposite (Travis et al., 1978). Like the ferret, embryo transfer has been applied to mink (Chang, 1968; Adams, 1982; Zhelezova \& Sekirina, 1982; Kraemer, 1983). This might be a very important technique for the mink industry in the 21 st century and we encourage scientists to make this expanding field of animal production fully available to mink farmers. It might be profitable to use mink as surrogate mothers for embryos from endangered species, such as the black-footed ferret.

\section{Reproductive biology of the male}

\section{Testicular development and spermatogenesis}

In the juvenile as well as the adult mink, consistent seasonal changes in testicular activity are observed. Testes are functional only during a few months around the breeding season in March (Onstad, 1967; Hemmingsen, 1967). After the breeding season, testes regress and remain very small and non-functional until the start of spermatogenesis again in November (Fig. 4). There is no correlation between body and testis weight (Onstad, 1967), but testicular and epididymal weights correlate with age (Askins \& Chapman, 1984). Although Onstad (1967) found evidence for a significantly larger left testis this could not be confirmed in a later study (Kostron \& Kukla, 1970).

In the newborn mink, the small testes $(0.03 \mathrm{~g})$ contain a fairly compact system of seminiferous tubules surrounded by the tunica albuginea (Fig. 5) (Onstad, 1967; Zaleska-Freljan, 1976). During that time the seminiferous tubules are lined with a single layer of Sertoli cells and a few developing 

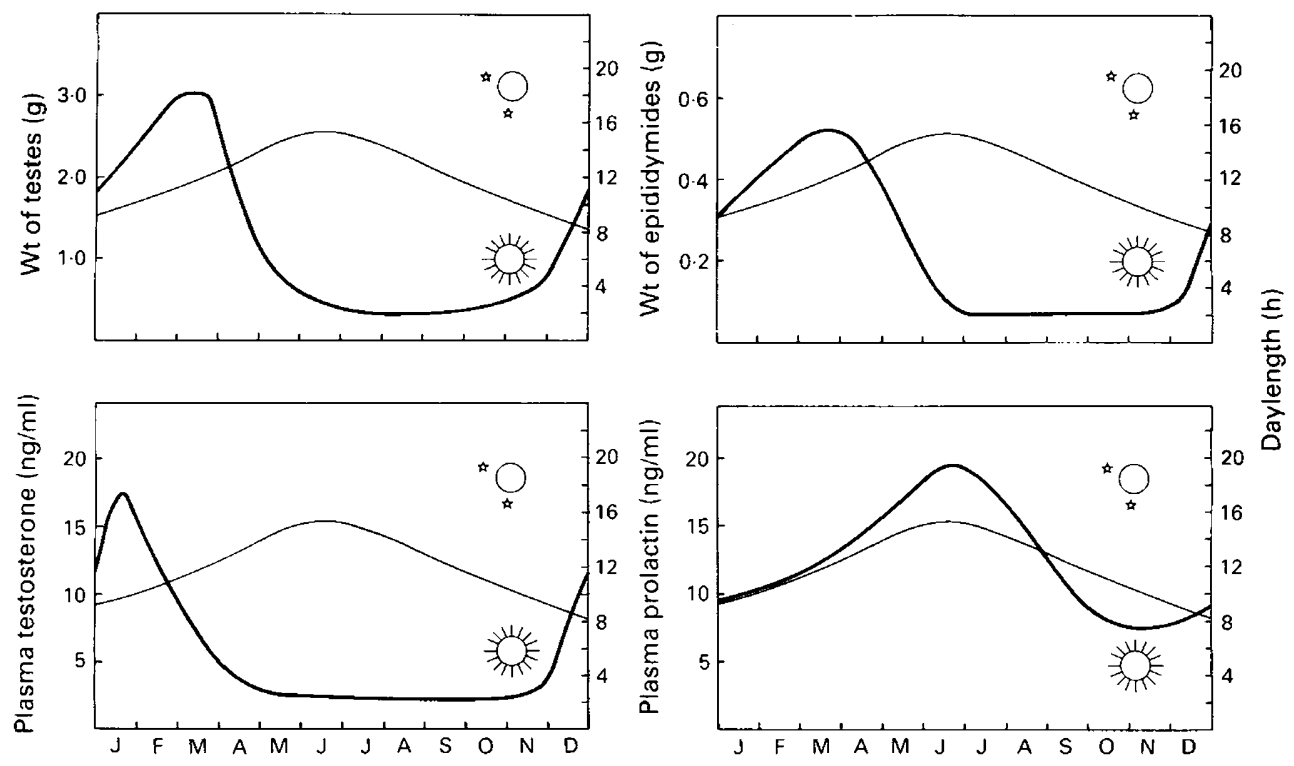

Fig. 4. Reproductive characteristics of the male mink as a function of the annual light-dark cycle. It should be noted that the male mink is an increasing daylength breeder.

spermatogonia (gonocytes). In addition to ovoid spermatogonia directly involved in spermatogenesis, larger undifferentiated spermatogonial stem cells seem to be particularly numerous during the inactive spermatogenic phase (Pelletier, 1986b). Between the tubules two different types of Leydig cells can be found, differing in their ability to accumulate lipids in their cytoplasm (Onstad, 1967; Zaleska-Freljan, 1976). In the adult mink, only one type of Leydig cell is observed. Cytologically, besides massive lipid accumulation, little evidence of activity is seen in these cells from June to October (Bostrom et al., 1968), and peripheral concentrations of testosterone, the main androgen produced by Leydig cells, do not increase until December (Nieschlag \& Bieniek, 1975; Pilbeam et al., 1979; Boissin-Agasse \& Boissin, 1979; Sundqvist et al., 1984; Goulevich et al., 1984). Support for decreased activity in Leydig cells is given by Bostrom et al. (1968) who found the nuclear to cytoplasmic ratio in Leydig cells to be 1 to 1.5 in October, compared with 1 to 2.0 in December, and finally 1 to $2 \cdot 5$ in February. Normally, testes descend during the 1 st month and remain scrotal throughout the life of the mink.

A relatively small change in testicular weight and functional capacity can be shown in kits during the first 7 months, and in adults from June to November (Onstad, 1967; Bostrom et al., 1968). Not until the end of October can any changes be seen in testicular cytology. A progressive increase in weight and spermatogenic activity is then observed until the onset of the mating season in March. Numerous active spermatogonia and one or two layers of rapidly dividing primary spermatocytes are seen at the end of November. Synaptonemal complexes are seen very often in primary spermatocytes and often also in round spermatids (Basrur \& Gilman, 1968). Great amounts of lipids and acid phosphatases are observed intratubularly (Onstad, 1967). The first maturation-phase spermatids are seen in December, and most mink have spermatozoa in the epididymal ducts by the middle of January (Onstad, 1967; Danilov \& Tumanov, 1972). In December most seminiferous tubules have a definite lumen, or the beginning of one (Onstad, 1967; Pelletier, 1986b). Pelletier (1986b) showed that the formation of a functional blood-testis barrier in December was consistent with the presence of a lumen in the tubules. When a fully developed lumen was present, the blood-testis barrier separated the spermatogonia and part of the 


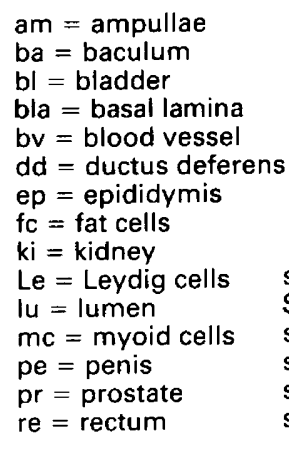

$\mathrm{sc}=$ scrotum

$\mathrm{Se}=$ Sertoli cells

spc $=$ spermatocytes

spg $=$ spermatogonia

$\mathrm{spt}=$ young spermatids

$\mathrm{spz}=$ maturation-phase spermatids and spermatozoa

ta $=$ tunica albuginea

te $=$ testis

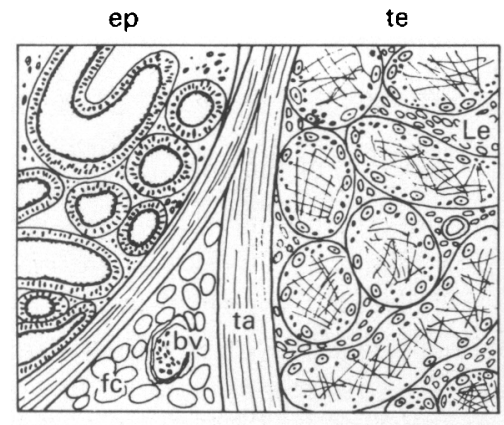

PREPUBERTAL TESTIS

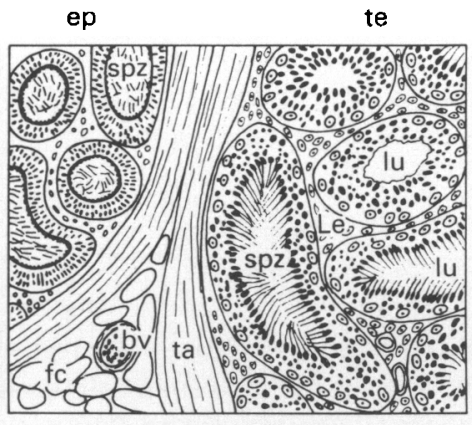

TESTIS DURING BREEDING SEASON

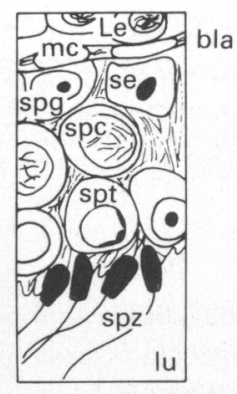

Iu

Fig. 5. The mink is characterized by profound seasonal changes in testicular activity. The schematic drawing shows typical features of a testis during regression (May-October) and during the mating season (March).

spermatocytes from the other germinal cells. During the active sexual phase, typical Sertoli cell junctional complexes were seen to be composed of continuous, as well as discontinuous, zonules and adhering junctions. After the active breeding season junctional complexes still exist, but they are permeable to filipin or horseradish peroxidase (Pelletier, 1986b; Pelletier \& Shivers, 1986), contrary to what is observed in other species. The partial breakdown of the blood-testis barrier is a significant feature found in non-seasonal mink and it has to be evaluated in further studies. The significance of these findings is discussed later in the context of male infertility problems. The blood-testis barrier is cyclically reformed at the beginning of active spermatogenesis in the adult.

During the breeding season in March, the mink testis weighs $\sim 3 \mathrm{~g}$ and the tubular diameter is 210-230 $\mu \mathrm{m}$ compared with 0.5 g and $111 \mu \mathrm{m}$ in August (Fig. 4) (Kostron \& Kukla, 1970, 1971). Three different types of spermatogonia (A, B, and intermediate) are seen. Primary spermatocytes are small in the preleptotene stage but increase in size considerably when they reach the pachytene stage. Differentiation of annulate lamellae is described in mink spermatids (Pelletier, 1986a). Considerable cell loss occurs during normal spermatogenesis (Onstad, 1967; Sundqvist, 1985). If we assume that Sertoli cells constitute a stable cell population, not changing in numbers after birth, spermatogenic efficiency can be calculated using germ cell:Sertoli cell ratios. The ratio of primary spermatocytes to Sertoli cells was found to be $2.37 \pm 0.06$ in the rat (Wing \& Christensen, 1982) and 2.69 \pm 0.42 in the mink (Sundqvist, 1985). An indicator of greater cell loss in the mink was 
found when calculating the ratio of round spermatids to Sertoli cells $(7.89 \pm 0.27$ and $4.61 \pm 0.59$ in rat and mink respectively). Differences exist in the kinetics of spermatogenesis before and during the breeding season (Tiba et al., 1968a, b; Tiba, 1973a, b, c). More data on other morphometric parameters of mink testicular cells can be found in the literature (Prasolov, 1979; Yoshida, 1982; Sundqvist, 1985).

During active spermatogenesis, germ cells are organized into a definite number of cellular associations comprising the stages of the seminiferous epithelial cycle. In the mink, the method of Roosen-Runge \& Giesel (1950) allowed classification of the cellular associations into 8 different stages (Onstad, 1967; Tiba et al., 1968a; Tiba, 1973d; Deguchi, 1978; Sakai, 1981). Use of Leblond \& Clermont's (1952) staging system, which is based on changes in the conformation of the acrosome system of developing spermatids, permitted identification of 12 different stages (Pelletier, 1986b).

Mink spermatozoa have a tadpole shape, with a head length of 5.8-7.0 $\mu \mathrm{m}$ and a width of $6.1 \mu \mathrm{m}$. The midpiece is $6.0 \mu \mathrm{m}$ long and the total length is $43.0 \mu \mathrm{m}$ (Kim et al., 1978a, 1979; Cummins \& Woodall, 1985). Epididymal spermatozoa show species specific swellings near the acrosome (Kim et al., 1979) and the morphology of cytoplasmic droplets has also been described (Krause et al., 1986). Although artificial insemination has been tried in the mink and the technique of deep-freezing the semen seems to be working (Ishikawa et al., 1965; Bernatskii \& Turbin, 1969; Pomytko et al., 1972; Ahmad et al., 1975a, b; Heron \& Rietveld, 1985b) reproductive results were not convincing, mainly due to problems with obtaining adequate semen samples, inducing ovulation at the proper time, or the inability of inseminated spermatozoa to pass the cervix (Bernatskii \& Rombe, 1978). For example, deposition of semen artificially into the uterus of mink treated with 200 i.u. PMSG and mated with vasectomized males on the previous day, resulted in a whelping rate of $66 \%$ (Pomytko et al., 1972). Semen can be successfully collected from most mink males by electroejaculation, but ejaculate volumes are very small (0.00l-0.2 ml) (Miljkovic et al., 1966; Pomytko et al., 1972; Aulerich et al., 1972; Jakovac et al., 1977).

There seem to be large individual differences in the length of the active breeding season. Fertile matings can take place in February or April but the general results of out-of-season matings must be considered doubtful (Ishikawa et al., 1965).

Hormones have been used in mink breeding to manipulate male reproduction, and sexual behaviour in castrated mink can be initiated by testosterone treatment, independent of the season (Chagvardieff et al., 1984). Human chorionic gonadotrophin was successfully used to increase male reproductive capacity (Valtonen et al., 1982) and clomiphene citrate increased the sperm count in infertile individuals (Lukola \& Sundqvist, 1986). However, it is not yet practical to use hormonal therapy to increase reproductive capacity in an ordinary farm situation. Due to the complexity in the regulation of reproductive hormones, and the difficulties in determining each animal's basal hormonal status, progress in this area has been very slow (Sundqvist, 1986).

Testicular regression begins at the end of March and although meiosis is still being completed at the end of May, no spermatozoa are seen in the testes. This may be related to the importance of a functional blood-testis barrier. Lipids in Leydig cells show a tendency to decrease during the mating season. This decrease is especially prominent just after the season (Onstad, 1967). The lumen is progressively absent in most, and later in all, tubules from April through November. No meiosis is completed after the end of June, and from July to September only occasional type $A_{1}$ spermatogonia are present along the basement membrane. During the regression, the size of the seminiferous tubules is reduced to about a third of its maximal size.

\section{Photoperiodic regulation of male reproduction}

Among the numerous mammals that exhibit an annual cycle of testicular activity, the mink, a short-day mammal, appears to hold a unique position. It is characterized by reactivation of testicular activity and seasonal gonadotrophic stimulation during decreasing photoperiod in autumn. The 
increase in the number and immunoreactivity of the hypothalamic LHRH-secreting neurones occurs in November (Boissin-Agasse et al., 1988). The annual plasma testosterone cycle is characterized by a very sharp peak in testosterone secretion (Fig. 4) (Martinet et al., 1978; Boissin-Agasse \& Boissin, 1979; Sundqvist et al., 1984). Under experimental conditions, it has been shown that a circadian rhythm is involved and that very short days ( $8 \mathrm{~h}$ light (L):16 h dark (D) or $4 \mathrm{~h} \mathrm{L:20} \mathrm{h} \mathrm{D)}$ were extremely effective in stimulating testicular activity (Boissin-Agasse et al., 1982; BoissinAgasse \& Ortavant, 1982; Klochkov, 1984; Ortavant et al., 1985). Restriction of light to $8 \mathrm{~h}$ per day between July and October stimulates spermatogenesis (Klochkov \& Kim, 1979; Klochkov, 1980) but continuous light given in the autumn arrests spermatogenesis (Klochkov et al., 1982). An abrupt change from $4 \mathrm{~h} \mathrm{L:20} \mathrm{h} \mathrm{D} \mathrm{to} 16 \mathrm{~h} \mathrm{~L}: 8 \mathrm{~h}$ D either inhibits testicular development or initiates gonadal atrophy (Duby \& Travis, 1972). Using asymmetrical photoperiods in a series of elegant experiments, it was possible to show that a 30 -min light pulse, given 12 or $16 \mathrm{~h}$ after the beginning of the main light period, inhibited testicular growth and steroidogenesis (Boissin-Agasse \& Boissin, 1985). However, if the extra light was given $8,10,18,20$ or $22 \mathrm{~h}$ after the beginning of the main light period, testes grew normally and secreted normal amounts of testosterone. Resonance experiments within a 24-h framework showed increased testicular activity and lower plasma prolactin concentrations when the period of the light-dark cycle was equal to 24 or $48 \mathrm{~h}$, but testicular activity remained unstimulated when the light-dark cycle was 12, 20 or $36 \mathrm{~h}$. These experiments clearly show that, although photoregulation of the annual cycle of testicular function is dependent on phase relationships between the daily cycle of photosensitivity and that of the photoperiod, the characteristics of the photoresponse are opposite to those described for long-day breeders (BoissinAgasse et al., 1986). Definite differences among colour varieties of mink are observed in the sensitivity of biological clocks to initiation of testicular development (Ellis et al., 1982b). The role of circadian rhythms in the photoregulation of testicular activity is not fully understood and this topic is beyond the scope of this review.

Plasma prolactin also seems to be regulated by a circadian cycle of photosensitivity. In contrast to long-day breeders, prolactin secretion in mink is maximal when testes are regressed in the summer and minimal when they are active in the spring (Fig. 4) (Martinet et al., 1982), i.e. an inverse relationship (Boissin-Agasse et al., 1983). The situation is even more complex during testicular regression and it is difficult to draw any conclusions about the possible causal relationship between the changes in prolactin release and testicular activity. It has also been proposed that an inverse correlation between the testis and thyroid cycles could represent an important internal signal for the end of the reproductive period. In fact, plasma thyroxine concentrations are highest during the spring and autumn months and lowest during winter (Boissin-Agasse et al., 1981). Thyroidectomy performed at the beginning of the breeding season stimulated testosterone production and prolonged the duration of maximum testicular development (Jacquet et al., 1986).

\section{Other aspects of male reproductive biology}

The spermatozoa pass from the seminiferous tubules to the epididymis in order to become functionally competent. The time required for mink spermatozoa to travel from the testis to the distal parts of the epididymis is unknown. As spermatozoa pass through the epididymal ducts they gradually show increased motility (Kim et al., 1978b). Testicular spermatozoa contain cytoplasmic droplets which diminish during their epididymal transit and only a few ejaculated spermatozoa contained droplets (Kim et al., 1979; Krause et al., 1986). Although the total head length of spermatozoa changed very little, anterior acrosomal length significantly decreased and postacrosomal length significantly increased during transit from the testis to the epididymis (Kim et al., 1978b). Little evidence of activity is seen in epididymides from June to November. The epididymal ducts are lined with low pseudostratified columnar epithelium with poorly developed stereocilia (Bostrom et al., 1968). A progressive increase in epididymal weight can be seen from December $(0 \cdot 28 \mathrm{~g})$ to March (0.56 g) (Fig. 4) (Bostrom et al., 1968). Morphologically, this weight gain results from 
the hypertrophy of the epithelial lining and smooth muscle fibres, an increase in sperm concentration, increased epithelial height, increased secretory activity, and the maximum development of stereocilia.

The accessory sex glands in the mink include a prostate and distinct ampullae (Fig. 5) (Basrur \& Ramos, 1973). The prostate is especially well developed and it completely surrounds the pelvic urethra. The size of the prostate reaches its maximum during the breeding season. Prostate secretion serves as a medium for transport of spermatozoa to the female. The ampullary glands are spindle-shaped enlargements composed of branched tubuli on the surface of the ductus deferens.

The mink penis is $\sim 5 \mathrm{~cm}$ long (Enders, 1952). It is enclosed in a sheath close to the ventral musculature. The corpora cavernosa unite to form the penis bone (baculum), a prominent feature which has been used as an accurate age criterion of wild mink (Popov, 1943; Elder, 1951; Paul, 1968; Long, 1969; Long \& Shirek, 1970).

\section{Reproductive problems in the female}

The economic situation of a mink farm can be measured by the number of live kits at pelting time per breeding female. Unfortunately, various factors cause negative effects, preventing achievement of maximum productivity. Good management, proper nutrition, accurate disease control, and attention to keeping good breeding records are known to be important factors leading to better reproductive results (Jørgensen, 1985; Heron \& Rietveld, 1985b). If fewer than 5.5-6 kits per mated female are produced, it is important to identify the factors minimizing the yield.

The sexual cycle of the mink differs from that of other laboratory animals. The mink may be classified as seasonally polyoestrous (Moshonkin, 1981). A convex oestrous curve has been described in unmated mink, but if they are mated, the oestrous cycle is changed to a curve consisting of peaks and troughs approximately 8 days apart. It is rather difficult to determine when a female mink is in oestrus (Jørgensen, 1985). Neither behaviour nor appearance of the external genitalia is a reliable indicator of possible mating response. Shackelford (1984) summarized these difficulties by stating that the female mink is in oestrus if she accepts the male. Mink farming pioneers experienced many females remaining unmated during the breeding season. With good management and strictly organized mating systems, taking into account the peculiarities in the oestrous cycle, the number of unmated females can nowadays be kept at a very low level (1-3\%). Hard to breed females might mate after treatment with reserpine to produce a sedative effect (LaFortune \& Rheault, 1960; Aulerich et al., 1962, 1964; Aulerich \& Schaible, 1964). The absence of ovulation after repeated mating was found to be an important cause of infertility (Nosova, 1977b). The incidence of female infertility is unusually high among 1 -year-old dark mink and a general lack of ovarian stimulation was observed in these animals (Ellis \& Pace, 1987).

The prevention of social stress by visually isolating the females led to better reproductive results, but isolated females come into full oestrus slightly later than do controls (Gilbert \& Bailey, 1967, 1969a, 1970; Hernesniemi, 1980). Females weaned before 8 weeks of age are easier to breed than females weaned at an older age (Gilbert \& Bailey, 1969b). When mink are exposed to noise, such as sonic booms or aircraft flying near the mink houses, either exceptionally high litter losses (Taylor, 1968) or no clear effects were reported (Travis et al., 1968, 1972, 1974). Sequential injections of pregnant mink with saline caused abortions that were interpreted as responses to the stress of handling and treatment (Daniel, 1971). The mink is a rather aggressive animal, and when considerable efforts are made to produce tamer mink, reproductive performance is improved (Belyaev \& Trapezov, 1986).

There appear to be differences in reproductive success and incidence of sterility among different genetic stocks (colour varieties) of mink (Skrivan et al., 1975; Jørgensen, 1985). Homozygosity for most recessive coat colour genes lowered fertility (Yamashita et al., 1965b). This was particularly 
apparent with the Aleutian gene which produced a significant decrease in fertility in the homozygous state (Evsikov \& Belyaev, 1968). About $20 \%$ of the females heterozygous for the shadow gene have various malformations of the uterus, cervix and vagina, preventing conception (Nes, 1965). Also, mink with the Stewart and Aleutian genes have very poor fertility (Johansson, 1965a). The Hedlund white mink is difficult to mate due to congenital deafness (Johansson, 1965b). Apparently due to inbreeding, extremely dark mink females have various genetic defects that cause loss of kits (Ellis et al., 1981a, 1982a; Ellis \& Pace, 1986).

A high prenatal death rate is reported in farm mink and it seems to be related to the length of gestation (Enders, 1952). According to Hansson (1947) $84 \%$ of the eggs ovulated are implanted, but only $50 \%$ of those result in kits due to increased mortality during the embryonic diapause. In Hedlund white mink the reproductive capacity is comparable to normal but an even higher proportion of kits tend to die (Johansson, 1965b). Kit mortality is also higher in females having the virally caused Aleutian disease (Jørgensen, 1985). The number of teats supplying milk does not correlate with the litter size, but is significantly and positively correlated with survival rate of the kits (Di \& Zou, 1983).

A large amount of research has been conducted to demonstrate the effect of different feeds on reproductive capacity. Generally speaking, the commonly found high prenatal mortality can be reduced by altering the diet (Broxup, 1968). This is an important step during implantation and pregnancy as well as during whelping and lactation. Nutritional causes accounted for $58 \%$ of the cases of anovulation (Chekalova, 1983).

The mink being a carnivore, dietary fat levels seldom affect reproduction, providing the fat is of good quality (Travis \& Schaible, 1961). The mink seems to need at least $18 \mathrm{~g}$ digestible protein per day, since lower levels of protein tend to impair reproductive performance (Skrede, 1978). The addition of B-complex vitamins to food containing only 7-8 g digestible protein increased fertility (Akimova, 1969). Serious vitamin $\mathbf{B}_{1}$ deficit caused by raw, thiaminase-containing fish, led to high embryonic mortality (Zimmermann, 1981). Also, $B_{2}$ and $B_{6}$ deficiency causes sterility primarily due to embryonic death (Helgebostad et al., 1963; Helgebostad, 1980). Poor reproductive results due to severe anaemia were obtained when mink were fed raw fish from the cod family (Helgebostad, 1968).

Infertility was increased in mink fed large amounts of acid-preserved fish silage during the breeding season (Jørgensen et al., 1976). Mink food is susceptible to microbial and enzymic decomposition and inferior reproductive results are reported when endotoxins from Escherichia coli were ingested by females after copulation (Møller \& Nordstoga, 1978). Addition of colistin, an antibiotic that inactivates endotoxins, to the diet improved reproductive results (Pekkanen $e t$ al., 1983).

Weight loss due to restricted feeding during the pre-mating period has negative effects on reproductive performance (Isupov et al., 1975; Tauson \& Alden, 1979, 1984, 1985) although opposite results have also been reported (Wenzel \& Schicketanz, 1980). Flushing (semi-starvation followed by re-feeding) improves reproductive performance (Tauson, 1985b).

Slaughter offal from the throat area (gullet trimmings) containing high levels of naturally occurring thyroactive compounds interferes with reproduction of female mink and with lactation (Travis et al., 1966; Kangas \& Mäkelä, 1972). Food containing cattle and pig uteri lowers reproductive success (Jarosz \& Barteczko, 1976). Poultry offal containing residuals of the food additive dienoestrol diacetate decreases the number of kits produced (Duby \& Travis, 1971).

Hormone-implanted poultry has been fed to mink with detrimental effects on reproduction (Howell \& Pickering, 1964). Experimentally, it was found that a daily intake of $10 \mu \mathrm{g}$ stilboestrol during the breeding season causes heavy kit losses (Mills, 1961; Shackelford \& Cochrane, 1962; Travis \& Schaible, 1962). Methandienone, an anabolic steroid, was used to improve fur quality artificially, and a dose of 0.44 or $1.8 \mathrm{mg}$ /day caused infertility in $50 \%$ and $100 \%$ of the females respectively (Westermarck et al., 1979). The anticoagulant Dicumarol has been reported to cause abortions (Kangas \& Mäkelä, 1974). 
For many years the fisheries of the Greak Lakes in the United States provided mink-ranching industries with an abundant and inexpensive supply of fish for feeding. Due to reports of severe reproductive complications and excessive kit mortality in mink fed these fish (Aulerich et al., 1970) detailed investigations were carried out to elucidate the factors responsible for these problems. Rancidity, pesticide contamination, and mercury poisoning were suspected causes (Aulerich et al., 1971,1973 ) until it was clearly shown that the mink is very sensitive to the polychlorinated biphenyls (PCBs) in these fish, especially if the percentage of chlorine was high (Aulerich \& Ringer, 1977). The mink ranks among the most sensitive of animals, particularly with regard to embryotoxicity (Aulerich et al., 1973) and the female is more sensitive than the male (Bleavins et al., 1980). In the mink, levels as low as $2-5$ p.p.m. PCB in the food caused complete reproductive failure while in the ferret 20 p.p.m. was the lowest level of PCB that induced reproductive complications (Bleavins et al., 1980; Ringer et al., 1981). PCB residues accumulate in the mink's subcutaneous fat reaching as much as 38 times the dietary level, with the half-life of PCB in adipose tissue being 98 days (Hornshaw et al., 1983). Ovulation and implantation occur in mink treated with PCB but gestation might not continue to term (Platonow \& Karstad, 1973; Jensen et al., 1977). It seems as if the mink can be fed up to 0.5 p.p.m. PCB in dry matter during the growing and furring period without any detrimental effects on reproduction (Rietveld, 1982). Increased plasma thyroxine concentrations are observed after PCB administration (Byrne et al., 1975). Chlorinated hydrocarbon pesticides (DDT) in the food apparently do not have any deleterious effects on the reproductive performance of the mink (Aulerich et al., 1971) although an occasional report of poorer reproduction has been published (Gilbert, 1969). Higher kit mortality has been reported in mink raised on heavily polluted farms near industrial areas (Jarosz \& Barabasz, 1984), and survival of mink kits is adversely affected by dietary levels of PCB and methylmercury currently present in some environments (Wren $e t$ al., 1987). High levels of iodine (>80 p.p.m.) result in a reduction in the number of females that whelp, a decrease in litter size and an increase in kit mortality (Aulerich et al., 1978; Jones et al., 1982), but reasonable doses of copper do not affect reproduction (Aulerich et al., 1982). Hexachlorobenzene (5-25 p.p.m.) causes a reduction in reproductive performance, and the mink is more sensitive to this substance than is the ferret (Rush et al., 1983; Bleavins et al., 1984).

\section{Reproductive problems in the male}

One problem of great economic consequence in the breeding of the mink is the presence of infertile males (Abramov \& Bernatskii, 1977; Sundqvist, 1986). Up to $20-30 \%$ of the males might have reproductive disturbances, and as the polygamic male is used for 4-8 females, the negative effect of male infertility rapidly multiplies, leading to groups of females without kits. It is important that these males be eliminated from breeding and several different methods have been developed for detecting mink male infertility. Testicular palpation (Onstad 1967; Venge, 1973; Sundqvist et al., 1986a) and the sperm test (Onstad, 1967; Sundqvist \& Gustafsson, 1983) are useful methods easily applied in a practical farm situation. However, the method of testicular palpation is largely restricted to the recognition of major testicular disturbances. Onstad (1967) suggested the week before the start of matings as the ideal time to palpate mink testes, but more recent studies (Sundqvist et al., 1986a) indicate that accurate and feasible palpation may be possible in early February. The sperm test offers a powerful tool in the breeding of mink although a contradictory report has been written (Venge, 1973). Reliable collection of semen samples from the mink is known to be difficult but representative samples can be collected from the vagina after interrupted coitus (Onstad, 1967; Sundqvist \& Gustafsson, 1983; Sundqvist et al., 1986a). Males producing semen of unsatisfactory quality can then be effectively eliminated. Prescreening of semen from infertile males can also be performed by electroejaculation, or samples can be collected directly from the epididymis using a lance (Graf, 1985; Heron \& Rietveld, 1986). The most useful and accurate method seems to be aspiration biopsy of the testis in order to detect defects in spermatogenesis (Sundqvist et al., 1986b). 
When scored on a scale from 1 to 10 according to the developmental stage and number of spermatogenic cells, males scoring 8-10 produced better breeding results than did males having scores under 7 (Sundqvist et al., 1986b, 1987). The biopsy did not adversely affect libido or fertility. By measuring plasma testosterone concentrations 1 month before the breeding season it was possible to detect males with delayed puberty or greatly disturbed testicular development (Sundqvist et al., 1984, 1985). Serum testosterone concentrations can be measured using solid-phase time-resolved fluoroimmunoassay with as great an accuracy as with a conventional radioimmunoassay (Bertoft $e t$ al., 1987). However, the testosterone test appears to give conflicting results (Sundqvist et al., 1986a) and must await further study before its real value can be determined.

The duration of copulation affects litter size in the mink (Kukla, 1971; Abramov \& Utkin, 1972). Males that copulated for less than $30 \mathrm{~min}$ fertilized fewer females than did those that copulated for more than $30 \mathrm{~min}$ (Kukla, 1977). Restriction of the duration of copulation to less than $6 \mathrm{~min}$ results in significantly reduced fertility, either due to too few spermatozoa ejaculated or defective sperm transport in the female genital tract (Venge, 1956a; Adams \& Rietveld, 1981). Although very short copulations usually are unproductive, pregnancy can result from intromissions of only $2 \mathrm{~min}$, provided these intromissions were preceded by some sort of ethological stimulation (Adams, 1973). An unusually high incidence of mink males not taking part in matings (3.29. $24.04 \%$ ) was reported in one study (Kukla, 1970). Histological examination revealed that spermatogenesis was normal in non-mating males (Kostron \& Kukla, 1970). In some males injection of testosterone propionate is able to induce mating (Chaddock, 1949). Adult mink males have more successful breeding attempts than young ones, with intromission latency averaging $12.6 \mathrm{~min}$ in adult mink and 15.4 min in young mink (MacLennan \& Bailey, 1972). Apparently experience rather than physiological factors was the cause of better success in the adult mink.

Defective testes are often found in mink (Hartung \& Seffner, 1983). Hypoplasia occurs in about $1.9 \%$ of the mink and $\sim 6.4 \%$ of the mink have cryptorchid testes (Sundqvist et al., 1986a). Both hypoplasia and cryptorchidism might be hereditary in the mink (Onstad, 1967). Furthermore, the mink differs from most other species in that the tunica vaginalis originates higher in the abdominal cavity and, instead of passing through the pelvis, it comes through an inguinal fat pad between the skin and the body wall. If the fat pad enlarges, the adipose cells might adhere to the tunica vaginalis and prevent the normal descent of testes (Ellis \& Pace, 1987). Most of the mink with hypoplastic testes produce semen of unsatisfactory quality (Onstad, 1961a, 1967; Sundqvist et al., 1986a). Males with small testes had a slightly poorer reproductive capacity than controls, but having larger testes did not significantly improve breeding performance of the male (Heron \& Rietveld, 1985a). A rare congenital defect characterized by lack of the epididymis has been described in mink (Onstad, 1961b; Blom \& Hermansen, 1969).

A much higher incidence of abnormal spermatozoa has been reported in the mink than in the fox (Borozdin \& Micurina, 1966). The following sperm abnormalities occur in the mink: coiled and bent tails, tailless spermatozoa, various sperm-head defects, and abnormal clumping of spermatozoa (Onstad, 1967; Sundqvist et al., 1986a). Fertility is less affected when the number of spermatozoa with primary morphological abnormalities falls below 6\% (Jarosz et al., 1968).

Mink that were abruptly changed from ambient light at $42^{\circ} \mathrm{N}$ latitude to an artificial light regimen corresponding to $45^{\circ} \mathrm{S}$ latitude showed very poor reproductive capacity after 9 months (Travis \& Pilbeam, 1980). Reproductive disturbances were also seen when mink were transported from the USA to Finland. There was a direct correlation between the time after arrival and the restoration of normal hormonal, reproductive and testicular status (Sundqvist et al., 1985). Exposure to artificial light during the winter months has a deleterious effect on reproduction (Venge, 1968). It might be important not to separate males too early from their native environment, as indicated by a much greater mating activity in males weaned at 11 weeks compared with those weaned at 6 weeks (Bassett et al., 1959).

There are great differences in male reproductive capacity between different colour varieties of mink, with Hedlund white males showing low levels of copulatory activity (Borisova, 1967) and 
males homozygous for the Stewart allele being sterile (Venge, 1963; Yamashita et al., 1965a). A significant increase in the incidence of polyploidy in bone marrow cells is seen in males with poor reproductive performance (Isakova, 1981). Males with poor libido and poor semen quality tended to be sex chromatin positive (Rauluszkiewicz et al., 1971). Sperm quality varies markedly in different colour varieties, with the poorest sperm quality being found in the sapphire mink and good sperm quality in the pastel and jet-black mink (Sundqvist et al., 1986a; Sundqvist \& Sundqvist, 1986).

Inbreeding mink for an extremely dark fur has co-selected for male infertility which might be observed at the onset of the breeding season (primary infertility) or after one or more fertile breeding seasons (secondary infertility) (Tung et al., 198 la, 1984). Mink expressing primary infertility have low plasma LH and testosterone concentrations. Since they respond to exogenous LHRH and hCG treatment it could be that these mink had defective LHRH secretion. Autoimmune orchitis and testicular immune complexes are frequently found in mink with secondary infertility (Tung et al., 1981a) and the extremely dark mink could be useful for studying autoimmune testicular disturbances (Tung et al., 1981a, b, 1985). Testicular autoimmune reactions most probably develop during testicular regression in late March and April. As indicated above, Pelletier (1986b) found a complete breakdown of the blood-testis barrier in the regressing mink testis and this might be the anatomical basis of autoimmune orchitis problems in the mink. Dark mink have a higher content of testicular histamine than do those of other colour varieties during the breeding season and the elevated secretion rate was related to the onset of autoimmune infertility (Nemetallah et al., 1985). Presumably histamine would induce the breakdown of the blood-testis barrier allowing the germ cells to be attacked by the immune system. Antibodies against germ cells are eventually produced and spontaneous destruction of the seminiferous epithelium starts (Ellis et al., 1985). The extremely dark mink differs from all other colour varieties so far studied, and although anti-sperm antibodies are found in other varieties, only the dark mink develops autoimmune orchitis. Natural killer cell activity was not higher in mink with autoimmune orchitis (Pace et al., 1987). Determining whether there is a causal relationship between the breakdown of the blood-testis barrier and the occurrence of immunopathological problems warrants future investigation. Extensive testicular damage in all colour varieties was observed after implantation of melatonin-containing capsules (Ellis, 1985).

Weight loss in male mink during the winter might have a deleterious effect on their reproductive performance (Tauson, 1985a), although obesity produces a similar effect (Alden \& Johansson, 1976). Precautions should be taken not to feed slaughter offal from hormone-implanted poultry, as it prevents the occurrence of normal reproductive activity (Howell \& Pickering, 1964).

Financial support from The Academy of Finland and The National Institutes of Health (HD20033) made this review possible. We thank Steve Rogers and Sherie L. Hodges for editing the text; Anthony Rietveld, for allowing use of the library at Northwood Fur Farms Inc.; Karen Schmitt, Cynthia Clabough and Cheryl Broadie for help with the illustrations; Dr Varadaraj Chandrashekar and Dr Artur Mayerhofer for helpful discussions; and Eric Dennison and David Nelson for assistance with the database. We apologize to those whose valuable contributions to the field have not been discussed or quoted due to unintentional omissions.

\section{References}

Abramov, M.D. (1960) Characteristics of the biology of reproduction of mink, Mustela vison Schreb. Nauchni Trud. nauchno-izsled. Inst. Pushn. Zverovod. Krolikovod. 5, 3-39.

Abramov, M.D. \& Utkin, L.G. (1972) The problem of interruption of copulation in mink. Nauchni Trud. nauchno-izsled. Inst. Pushn. Zverovod. Krolikovod. 11, $194-195$.
Abramov, M.D. \& Bernatskii, V.G. (1977) Some causes of infertility in mink and methods for eliminating it. Nauchni Trud. nauchno-izsled. Inst. Pushn. Zverovod. Krolikovod. 15, 5-12.

Adams, C.E. (1973) The reproductive status of female mink, Mustela vison, recorded as 'failed to mate'. $J$. Reprod. Fert. 33, 527-529.

Adams, C.E. (1981) Observations on the induction of 
ovulation and expulsion of uterine eggs in the mink, Mustela vison. J. Reprod. Fert. 63, 241-248.

Adams, C.E. (1982) Egg transfer in carnivores and rodents, between species and to ectopic sites. In Mammalian Egg Transfer, pp. 49-6I. Ed. C. E. Adams. CRC Press Inc., Boca Raton.

Adams, C.E. \& Rietveld, A.A. (1981) Duration of copulation and fertility in the mink, Mustela vison. Theriogenology 15, 449-452.

Ahmad, M.S., Kitts, W.D. \& Krishnamurti, C.R. (1975a) Mink semen studies. I. Liquid preservation and prospect of freezing spermatozoa. Theriogenology 4, 1522.

Ahmad, M.S., Kitts, W.D. \& Krishnamurti, C.R. (1975b) Mink semen studies. II. Freeze-preparation of spermatozoa. Theriogenology 4, 77-82.

Akimova, T.I. (1969) The effect of B group vitamins on fertility of breeding mink. Nauchni Trud. nauchnoizsled. Inst. Pushn. Zverovod. Krolikovod. 8, 149-157.

Alden, E. \& Johansson, A-H. (1976) Effects of different feeding intensity on reproduction, growth and fur quality of mink. Proc Ist Int. Sci. Congr. Fur Anim. Prod., Helsinki, p. I, Abstr.

Allain, D., Martinet, L. \& Rougeot, J. (1981) Effect of melatonin implants on changes in the coat, plasma prolactin level and testis cycle in the mink (Mustela vison). In Photoperiodism and Reproduction in Vertebrates. pp. 263-271. Eds R. Ortavant, J. Pelletier \& J. P. Ravault. INRA Publ., Paris.

Allais, C. \& Martinet, L. (1978) Relation between daylight ratio, plasma progesterone levels and timing of nidation in mink (Mustela vison). J. Reprod. Fert. 54, 133-136.

Askins, G.R. \& Chapman, J.A. (1984) Age determination and morphological characteristics of wild mink from Maryland, USA. Z. Saugetierk. 49, 182-189.

Aulerich, R.J. \& Schaible, P.J. (1964) Use of tranquilizer for hard-to-breed female mink. Q. Bull. Mich. Agric. Exp. Stn 47, 220-224.

Aulerich, R.J. \& Ringer, R.K. (1977) Current status of PCB toxicity to mink, and effect on their reproduction. Archs Environ. Contam. Toxicol. 6, 279-292.

Aulerich, R.J., Shelts, G., Ringer, R.K. \& Schaible, P.J. (I962) The value of reserpine in colony rearing of mink. Q. Bull. Mich. Agric. Exp. Stn 45, 246-251.

Aulerich, R.J., Holcomb, L.C., Ringer, R.K. \& Schaible, P.J. (1963) Influence of photoperiod on reproduction in mink. Q. Bull. Mich. agric. Exp. Stn 46, 132-138.

Aulerich, R.J., Shelts, G., Ringer, R.K. \& Schaible, P.J. (1964) Further uses of reserpine in colony rearing of mink. Q. Bull. Mich. Agric. Exp. Stn 47, 416.

Aulerich, R.J., Ringer, R.K., Schaible, P.J. \& Seagran, H.L. (1970) An evaluation of processed Great Lakes fishery products for feeding mink. Feedstuffs 42, 48.

Aulerich, R.J., Ringer, R.K., Seagran, H.L. \& Youatt, W.G. (1971) Effects of feeding coho salmon and other Great Lakes fish on mink reproduction. Can.J. Zool. 49, 611-616.

Aulerich, R.J., Ringer, R.K. \& Sloan, C.S. (1972) Electroejaculation of mink (Mustela vison). J. Anim. Sci. 34, $230-233$.

Aulerich, R.J., Ringer, R.K. \& Iwamoto, S. (1973) Reproductive failure and mortality in mink fed on Great Lakes fish. J. Reprod. Fert., Suppl. 19, 365-376.
Aulerich, R.J., Ringer, R.K. \& Hartsough, G.R. (1978) Effect of iodine on reproductive performance of female mink. Theriogenology 9, 295-303.

Aulerich, R.J., Ringer, R.K., Bleavins, M.R. \& Napolitano, A. (1982) Effects of supplemental dietary copper on growth, reproductive performance and kit survival of standard dark mink and the acute toxicity of copper to mink. J. Anim. Sci. 55, 337-343.

Baevsky, U.B. (1961) Some peculiarities of embryonic diapause in the mink (Mustela vison Schreb.) Dokl. Akad. Nauk. SSSR 139, 499-502.

Baevsky, U.B. (1963) The effect of embryonic diapause on the nuclei and mitotic activity of mink and rat blastocysts. In Delayed Implantation, pp. 141-153. Ed. A. C. Enders. Chicago University Press, Chicago.

Basrur, P.K. \& Gilman, J.P.W. (1968) Synaptinema-like complex in spermatids of some Mustelids. Can. J. Genet. Cytol. 10, 426-432.

Basrur, P.K. \& Ramos, A.S. (1973) Seasonal changes in the accessory sex glands and gonaducts of male mink. Can. J. Zool. 51, 1125-1132.

Bassett, C.F., Travis, H.F., Abernathy, R.P. \& Warner, R.G. (1959) Relationship between age at separation and subsequent breeding performace of growing male mink. J. Mammal. 40, 247-248.

Belyaev, D.K. \& Trapezov, O.V. (1986) The relationship of selection for behaviour with reproduction in American mink. Zh. Obshch. Biol. 47, 445-450.

Belyaev, D.K., Klochkov, D.V. \& Zhelezova, A.J. (1963) The influence of light condition on the reproductive function and fertility in mink (Mustela vison Schr.). Byull. mosk. Obshch. Ispȳt. Prir. Otd. Biol. 78, 107125.

Bernatskii, V.G. (1971) Effect of subsequent mating on fate of fertilized ova in mink. Nauchni Trud. nauchnoizsled. Inst. Pushn. Zverovod. Krolikovod. 10, 138 141 .

Bernatskii, V.G. (1983) The duration of pregnancy in mink in relation to the date of mating, age and colour. Nauchni Trud. nauchno-izsled. Inst. Pushn. Zverovod. Krolikovod. 29, 93-100.

Bernatskii, V.G. \& Diveeva, G.M. (1981) The nature of sexual cyclicity of female mink. Nauchni Trud. nauchno-izsled. Inst. Pushn. Zverovod. Krolikovod. 26, 96-99.

Bernatskii, V.G. \& Nosonova, N.G. (1968) Changes in the genital apparatus and thyroid gland of PMS-treated female mink during the period of quiescence. Nauchni Trud. nauchno-izsled. Inst. Pushn. Zverovod. Krolikovod. $7,38-41$.

Bernatskii, V.G. \& Polyntsev, Y.V. (1982) The concentration of steroid hormones in the blood of mink after a hormonal treatment during oestrus. Nauchni Trud. nauchno-izsled. Inst. Pushn. Zverovod. Krolikovod. 27, 102-110.

Bernatskii, V.G. \& Rombe, S.M. (1978) Problems of artificial insemination of mink related to the anatomy of their genitalia and physiology of coitus. Nauchni Trud. nauchno-izsled. Inst. Pushn. Zverovod. Krolikovod. 17, 57-60.

Bernatskii, V.G. \& Turbin, V.F. (1969) Obtaining epididymal semen from mink, its storage and utilization. Nauchni. Trud. nauchno-izsled. Inst. Pushn. Zverovod. Krolikovod. 8, 137-139. 
Bernatskii, V.G., Kruglova, N.M. \& Rapoport, I.A. (1977) Improving the reproductive performance of mink by stimulation of the vagina and testes. Nauchni Trud. nauchno-izsled. Inst. Pushn. Zverovod. Krolikovod. 15, 33-37.

Bertoft, E., Mäentausta, O., Sundqvist, C. \& Lukola, A. (1987) Comparison between radioimmunoassay and a new time-resolved fluoroimmunoassay: determination of total testosterone in male mink (Mustela vison). Anim. Reprod. Sci. 12, 291-296.

Bleavins, M.R., Aulerich, R.J. \& Ringer, R.K. (1980) Polychlorinated biphenyls (Aroclors 1016 and 1242): Effects on survival and reproduction in mink and ferrets. Archs Environ. Contam. Toxicol. 9, 627-635.

Bleavins, M.R., Aulerich, R.J. \& Ringer, R.K. (1984) Effects of chronic dietary Hexachlorobenzene exposure on the reproductive performance and survivability of mink and European ferrets. Archs Environ. Contam. Toxicol. 13, 357-365.

Blom, E. \& Hermansen, E. (1969) Segmental aplasia of the Wolffan duct (lack of epididymis), a sterilizing and hereditary defect in the mink. Nord Vet Med. 21, 188-192.

Boissin-Agasse, L. \& Boissin, J. (1979) Variations saisonnieres du volume testiculaire et de la testosteronemie chez deux mustelides: le furet (Mustela furo) et le vison (Mustela vison). J. Physiol., Paris 75, 227-232.

Boissin-Agasse, L. \& Boissin, J. (1985) Incidence of circadian cycle of photosensitivity in the regulation of the annual testis cycle in the mink: a short-day mammal. Gen. comp. Endocrinol. 60, 109-115.

Boissin-Agasse, L. \& Ortavant, R. (1982) Circadian photosensitive phase and photoperiodic regulation of testicular activity in long-day (ferret) and short-day (mink) breeding mammals. In Photoperiodism and Reproduction in Vertebrates, pp. 51-66. Eds R. Ortavant, J. Pelletier \& J. P. Ravault. INRA, Paris.

Boissin-Agasse, L., Maurel, D. \& Boissin, J. (1981) Seasonal variations in thyroxine and testosterone levels in relation to the moult in the adult male mink (Mustela vison Peale and Beauvois). Can. J. Zool. 59, $1062-1066$.

Boissin-Agasse, L., Boissin, J. \& Ortavant, R. (1982) Circadian photosensitive phase and photoperiodic control of testis activity in the mink (Mustela vison Peale and Beauvois), a short-day mammal. Biol. Reprod. 26, $110-119$.

Boissin-Agasse, L., Ravault, J-P. \& Boissin, J. (1983) Evidence for a circadian rhythm in photosensitivity involved in the photoperiodic control of annual cycle in plasma prolactin in the male mink. $C$. r. hebd. Séanc. Acad. Sci. Paris D 296, 707-710.

Boissin-Agasse, L., Jacquet, J.M., Lacroix, A. \& Boissin, J. (1986) Circadian participation in the photoregulation of testis activity and prolactin secretion in the mink, a short-day breeder. J. biol. Rhythms 1, 231241.

Boissin-Agasse, L., Alonso, G., Roch G. \& Boissin, J. (1988) Peptidergic neurohormonal systems in the basal hypothalamus of the ferret and the mink: Immunocytochemical study of variations during the annual reproductive cycle. Cell Tissue Res. 251, 153159.
Borisova, S.K. (1967) An inherited cause of low activity in male white mink. Uchen. Zap. Petrozavodsk. Univ. 15, 96-99.

Borozdin, E.K. \& Micurina, L.R. (1966) Semen quality of fur bearers. Trūdy nauchno-issled. Inst. sel'. Khoz. krain. Sev. 13, 207-212.

Bostrom, R.E., Aulerich, R.J., Ringer, R.K. \& Schaible, P.J. (1968) Seasonal changes in the testes and epididymides of the ranch mink (Mustela vison). Q. Bull. Mich. Agric. Exp. Stn 50, 538-558.

Bowness, E.R. (1942) Gestation period in mink. Vet. Med. 37, 407.

Bowness, E.R. (1968) A survey of the gestation period and litter size in ranch mink. Can. vet. J. 9, 103-106.

Broxup, B. (1968) Faulty nutrition of mink as a cause of a reduction in the litter size. J. Small Anim. Pract. 9, 109-115.

Bura, M., Rebreanu, L. \& Crisan, S. (1981) Effect of temperature on gestation length in mink. Lucr. stiint. Inst. agron. Timis zootech. 18, 254-257.

Busch, L.C. (1976) Zur hypophysären Kontrolle der Follikelreifung beim Farmnerz (Mustela vison dom). Verh. anat Ges. Jena 70, 159-164.

Busch, L.C., Kühnel, W. \& Stang-Voss, C. (1979) The ultrastructure of the vaginal epithelium of the mink (Mustela vison Schreb.) during the reproductive cycle. Acta morph. neerl. scand. 17, 210-211.

Byrne, J.J., Reineke, E.R., Ringer, R.K. \& Aulerich, R.J. (1975) Influences of polychlorinated biphenyl mixture (Aroclor 1254) administration on reproduction and thyroid function in mink (Mustela vison). Fedn Proc. Fedn Am. Socs exp. Biol. 34, 321, Abstr.

Byskov, A.G. (1975) The role of the rete ovarii in meiosis and follicle formation in the cat, mink and ferret. $J$. Reprod. Fert. 45, 201-209.

Canivenc, R. \& Bonnin-Laffargue, M. (1967) Luteal asthenia in species with delayed implantation (Meles meles, Mustela vison). Rev. Eur. Endocrinol. 4, 29-40.

Canivenc, R., Bonnin-Laffargue, M. \& Lajus, M. (1966) Has pregnant uterus a luteotrophic function in mink? C. r. Séanc. Soc. Biol. 160, 2285-2287.

Chaddock, T.T. (1949) Breeding problems encountered in newer mutation mink. Am. Fur Breeder 22, 42, 44, 46.

Chagvardieff, C., Martinet, L. \& Allain, D. (1984) Androgenic induction of sexual behaviour in castrated mink during three different periods of the year. Proc. 3rd Int. Sci. Congr. Fur Animal Prod. Versailles, p. 39, Abstr.

Chang, M.C. (1968) Reciprocal insemination and egg transfer between ferrets and mink. J. exp. Zool. 168, 49-60.

Chanin, P. (1983) Observations on two populations of feral mink in Devon, U.K. Mammalia 47, 463-476.

Chekalova, T.M. (1983) The reproductive function of mink females. Sb. nauch. Trud. mosk. vet. Akad. pp. 104-106.

Christiansen, I.J. (1985) Attempts to advance implantation in mink by means of treatment with medroxyprogesterone acetate. K. Vet.-og Landbohoisk. Inst. Sterilitetsforskn. Aarsberetn. 28, 55-60.

Cochrane, R.L. \& Shackelford, R.M. (1962) Effects of exogenous oestrogen alone and in combination with progesterone on pregnancy in the mink. J. Endocr. 25, 101-106. 
Conant, R.A. (1962) A milking technique and the composition of mink milk. Am. J. vet. Res. 23, $1104-1106$.

Concannon, P., Pilbeam, T. \& Travis, H. (1980) Advanced implantation in mink (Mustela vison) treated with medroxyprogesterone acetate during early embryonic diapause. $J$. Reprod. Fert. 58, 1-6.

Cummins, J.M. \& Woodall, P.F. (1985) On mammalian sperm dimensions. J. Reprod. Fert. 75, 153-175.

Daniel, J.C. (1967) Studies on growth of the mink blastocyst. J. Embryol. exp. Morph. 17, 293-302.

Daniel, J.C. (1971) Termination of pregnancy in mink by repeated injections during the period preceding implantation. J. Anim. Sci. 33, 659-661.

Danilov, P.I. \& Tumanov, I.L. (1972) Reproductive cycles of males in some Mustelidae. Zool. Zh. 51, 871-880.

Danilov, P.I. \& Tumanov, I.L. (1975) The reproductive cycle of some females of the Mustelidae family. Byull. mosk. Obshch. Ispȳt. Prir. Otd. Biol. 80, 137-146.

David, G.F.X. \& Herbert, J. (1973) Experimental evidence for a synaptic connection between habenula and pineal ganglion in the ferret. Brain Res. 64, 327343 .

Deguchi, E. (1978) Histological studies on the kinetics of the spermatogenesis in the mink (Mustela vison). VII. Cellular association in the seminiferous epithelium in the pre-breeding season (16 months old). Jpn $J$, vet. Res. 26, 1-10.

Di, R.H. \& Zou, X.H. (1983) The effect of teat number on reproduction of female mink. Fur Animal Farming 1, 8-9.

Donofrio, R.J. (1974) Cyclic AMP in the median eminence of the rat and mink (Mustela vison). Anat. Rec. 178, 345, Abstr.

Drekic, D., Jablan-Pantic, O. \& Miladinovic, Z. (1981) Morphological properties of mink (Mustela vison) brain. Folia morph. (Praha) 29, 128-130.

Duby, R.T. \& Travis, H.F. (1971) Influence of dienestrol acetate on reproductive performance of female mink. Am. J. vet. Res. 32, 1599-1602.

Duby, R.T. \& Travis, H.F. (1972) Photoperiodic control of fur growth and reproduction in the mink (Mustela vison). J. exp. Zool. 182, 217-225.

Duby, R.T., Pilbeam, T. \& Travis, H.F. (1972) The influence of melatonin and hysterectomy on plasma progesterone levels of the mink (Mustela vison). Biol. Reprod. 7, 125, Abstr.

Dukelow, W.R. (1966) Variations in gestation length of mink (Mustela vison). Nature, Lond. 211, 211.

Dunstone, N. (1986) The mink. Biologist 33, 69-75.

Einarsson, E.J. (1985) The time of increase in plasma progesterone during pregnancy in mink (Mustela vison). Theriogenology 24, 375-383.

Elder, W.H. (1951) The baculum as an age criterion in mink. J. Mammal. 32, 43-50.

Ellis, L.C. (1985) Early furring, testicular development and cytotoxic lesions of testes and epididymides of dark mink by melatonin implants. In Pineal Gland: Endocrine Aspects, pp. 145-150. Eds G. M. Brown \& S. D. Wainwright. Pergamon Press, New York.

Ellis, L.C. \& Pace, N. (1986) Watery kits and neonatal kit loss: factors responsible for mortality. Blue Book of Fur Farming 1987; 58-61.

Ellis, L.C. \& Pace, N.C. (1987) Genetic problems-a look at today's dark mink. Fur Rancher 67, 10-13.
Ellis, L.C., Groesbeck, M.D. \& Howell, R.E. ( 1981 a) Production problems in finely-bred dark mink. Blue Book of Fur Farming 1982, 20-21, 65, 88.

Ellis, L.C., Groesbeck, M.D., Farr, C.H. \& Tesi, R.J. (1981b) Contractility of seminiferous tubules as related to sperm transport in the male. Archs Androl. 6, 283-294.

Ellis, L.C., Nemetallah, B.H. \& Howell, R.E. (1982a) Management of secondary male infertility and neonatal mortality in dark mink. Blue Book of Fur Farming 1983, 67-70.

Ellis, L.C., Groesbeck, M.D. \& Howell, R.E. (1982b) Pineal gland-pituitary ( $\alpha$-MSH) interrelationships in fur priming and reproductive cycles in mink (Mustela vison). Prog. Clin. Biol. Res. 92, 197-206.

Ellis, L.C., Groesbeck, M.D., Smart, R.A. \& Cosentino, M.J. (1985) Spontaneous autocytochemical destruction of dark mink testes and epididymides. J. Androl. 6, 68, Abstr.

Enders, A.C. (1957) Histological observations on the chorio-allantoic placenta of the mink. Anat. Rec. 127, 23 l-245.

Enders, A.C. (1960) Morphological evidence of fluctuation in hormone levels in mink in the period of delayed implantation. Anat. Rec. 137, 352, Abstr.

Enders, A.C. (1961) Comparative studies on the endometrium of delayed implantation. Anat. Rec. 139, 483497.

Enders, A.C. (1962) Observations on the fine structure of lutein cells. J. Cell Biol. 12, 101-113.

Enders, A.C., Enders, R.K. \& Schlafke, S. (1963) An electron microscope study of the gland cells of the mink endometrium. J. Cell Biol. 18, 405 418.

Enders, R.K. (1938) The ovum of the mink (Mustela vison). Anat. Rec. 72, 469-471.

Enders, R.K. (1948) Induced mating in ovariectomized mink. Anat. Rec. 100, 738, Abstr.

Enders, R.K. (1949) Multiple ovulation in mink breeding. Am. Fur Breeder 21, 6, 8.

Enders, R.K. (1952) Reproduction in the mink (Mustela vison). Proc. Am. Philos. Soc. 96, 691-755.

Enders, R.K. \& Pearson, A.K. (1946) Mink blastocysts in vitro. Anat. Rec. 96, 570, Abstr.

Enders, R.K. \& Enders, A.C. (1963) Morphology of the female reproductive tract during delayed implantation in the mink. In Delayed Implantation, pp. 129 140. Ed. A. C. Enders. Chicago University Press, Chicago.

Evsikov, V.I. \& Belyaev, D.K. (1968) Genetic aspects of reproduction in the mink (Lutreola vison Brisson). Proc. 6th Int. Cong. Anim. Reprod. \& A.I., Paris, p. 252, Abstr.

Fiedler, J., Skrivan, M. \& Siler, R. (1975) Influence of repeated mating on litter size in standard minks. Zivočišna výroba 20, 687-692.

Franklin, B.C. (1958) Studies on the effects of progesterone on the physiology of reproduction in the mink, Mustela vison. Ohio J. Sci. 58, 163-170.

Friend, D.W. \& Crampton, E.W. (1960) Observations on the effect of four mating routines for female mink. Can. J. comp. Med. Vet. Sci. 24, 3-5.

Gilbert, F.F. (1969) Physiological effects of natural DDT residues and metabolites on ranch mink. J. Wildl. Mgmt 33, 933-943. 
Gilbert, F.F. \& Bailey, E.D. (1967) The effect of visual isolation on reproduction in the female ranch mink. J. Mammal. 48, 113-118.

Gilbert, F.F. \& Bailey, E.D. (1969a) Visual isolation and stress in female ranch mink particularly during the reproductive season. Can. J. Zool. 47, 209-212.

Gilbert, F.F. \& Bailey, E.D. (1969b) The effect of early weaning on the sexual behavior and reproductive success of ranch mink. J. Mammal. 50, 742-747.

Gilbert, F.F. \& Bailey, E.D. (1970) Reproductive performance of three genetic strains of female mink isolated after breeding. Cornell Vet. 60, 135-138.

Ginther, O.J., Bergfelt, D.R., Scraba, S.T., Pivonka, P.R. \& Nuti, L.C. (1985) Effects of 6-MBOA on reproductive function in ponies, mice, rats and mink. Theriogenology 24, 587--595.

Goulevich, R.G., Osadchuk, L.V. \& Klochkov, D.V. (1984) Endocrine function in the gonads in males of two genotypes of the mink Mustela vison. J. Evol. Biochem. Physiol. 20, 316-318.

Graf, Z. (1985) Development and use of an electroejaculator for zoo and domestic animals. Magy. Allatorv. Lap. 40, 169-174.

Gulamhusein, A.P. \& Thawley, A.R. (1972) Ovarian cycle and plasma progesterone levels in the female stoat, Mustela erminea. J. Reprod. Fert. 31, 492-493.

Gulyas, B.J., Daniel, J.C. \& Krishnan, R.S. (1969) Incorporation of labelled nucleosides in vitro by rabbit and mink blastocysts in the presence of blastokinin or serum. J. Reprod. Fert. 20, 255-262.

Gunn, C.K. (1949) Mink Ranching. Publ. Dept. Agric. Canada. No. 827, 60 pp.

Hammond, J. (1951a) Control by light of reproduction in ferrets and mink. Nature, Lond. 167, 150-151.

Hammond, J. (1951b) Failure of progesterone treatment to affect delayed implantation in the mink. J. Endocr. $7,330-334$.

Hammond, J. (1952) Gonadotrophin-induced ovulation in mink. J. Mammal. 33, 218-233.

Hansson, A. (1947) The physiology of reproduction in mink (Mustela vison, Schreb.) with special reference to delayed implantation. Acta zool. (Stockh.) 28, 1-136.

Hartsough, G.R. (1942) A report on the use of Gonadin in mink. Am. Fur. Breeder 14, 18-19.

Hartung, J. \& Seffner, W. (1983) Fortpflanzungsstörungen bei Nerzrüden. Mschr. VetMed. 38, 611-617.

Hattenhauer, H. (1984) Effect of GnRH vet. "Berlin Chemie" on reproductive performance of mink. Mschr. VetMed. 39, 271-273.

Hattenhauer, H. \& Pötschulat, A. (1984) Experimental use of GnRH vet. "Berlin-Chemie" for single mating of mink females. Mschr. VetMed. 39, $524-527$.

Hattenhauer, H., Pingel, H. \& Elze, K. (1984) Use of PMSG and hCG in mink breeding. Mschr. VetMed. 39, $520-523$.

Hedlund, K., Nilsson, O., Reinius, S. \& Åman, G. (1972) Attachment reaction of the uterine luminal epithelium at implantation: light and electron microscopy of the hamster, guinea-pig, rabbit and mink. J. Reprod. Fert. 29, 131-132.

Helgebostad, A. (1968) Anaemia in the mink. Nord. VetMed. 20, 161-172.

Helgebostad, A. (1980) Embryonic death in mink due to riboflavine deficiency. Nord. VetMed. 32, 313-317.
Helgebostad, A., Svenderup, R. \& Ender, F. (1963) Sterility in mink induced experimentally by deficiency of vitamin $\mathrm{B}_{6}$. Acta vet. scand. 4, 228-233.

Hemmingsen, B. (1967) Postnatal development and cyclic changes in the testes of mink. Nord. VetMed. 19, 7180.

Hernesniemi, E. (1980) The effect of visual isolation on mink reproduction. Scientifur 4, 21-24.

Heron, L. \& Rietveld, A.A. (1985a) Is there a correlation between testicle size and reproductive performance? Scientifur 9, 296.

Heron, L. \& Rietveld, A.A. (1985b) A digest of Dr Cyril Adams's research on mink reproduction. Scientifur 9 , 297-300.

Heron, L. \& Rietveld, W. (1986) An approach to selection for male reproductive performance. 10th Ann Short Course, Mishicot, Wisconsin, 6 pp.

Hodgson, R.G. (1945) The mink book. Fur Trade Jl Can., Toronto, $284 \mathrm{pp}$

Hodgson, R.G. (1958) The mink book. Fur Trade Jl Can., Toronto, $272 \mathrm{pp}$.

Holcomb, L.C. (1967) Effects of progesterone treatments on delayed implantation in mink. Ohio J. Sci. 67, 24 31.

Holcomb, L.C., Schaible, P.J. \& Ringer, R.K. (1962) The effects of varied lighting regimes on reproduction in mink. Q. Bull. Mich. Agric. Exp. Stn 44, 666-678.

Hornshaw, T.C., Aulerich, R.J. \& Johnson, H.E. (1983) Feeding Great Lakes (USA, Canada) fish to mink: effects on mink and accumulation and elimination of polychlorinated biphenyls by mink. J. Toxicol. Environ. Health 11, 933-946.

Howell, J.M. \& Pickering, C.M. (1964) Suspected synthetic oestrogen poisoning in mink. Vet. Rec. 76, $169-170$.

Isakova, G.K. (1981) Polyploidy in the bone marrow and spermatogenic epithelium of male mink of differing fertility. Genetika 17, 858-872.

Ishikawa, R., Tiba, T., Kagota, K., Kawabe, K. \& Kinoshita, S. (1965) Experimental study of artificial insemination in mink. Jpn. J. vet. Res. 13, 1-16.

Isupov, B.A., Barantseva, E.D., Kulikova, T.G., Kryakin, A.A. \& Yureva, I.M. (1975) The effect of nutritional level of mink before the breeding season and during pregnancy on the yield of progeny. $S b$. nauchno-tekh. Inform. vses. nauchno-issled. Inst. Okhot. Khoz. Zverovod. 49, 150-157.

Jacquet, J-M., Coutant, C., Maurel, D., Boissin-Agasse, L. \& Boissin, J. (1986) Effects of thyroidectomy on spring and summer variations in testis activity and plasma prolactin in the mink. C. r. hebd. Séanc. Acad. Sci., Paris 303 (Ser. III), 367-370.

Jakovac, M., Kopljar, M., Grabar, B., Kos, M. \& Saric, B. (1977) Semen collection in male mink (Mustela vison) by electroejaculation. Vet. Arh. 47, 95-98.

Jarosz, S. \& Barteczko, J. (1976) The effect of rations containing bovine and porcine uteri, fish and fat on fertility and fecundity of mink. Zesz. Probl. Postepow. Nauk. Roln. 180, 491-498.

Jarosz, S. \& Barabasz, B. (1984) Effect of environmental factors on fertility in mink. Proc. 3rd Int. Sci. Congr. Fur Animal Prod., Versailles, p. 27, Abstr.

Jarosz, S.J. \& Dukelow, W.R. (1985) Effect of progesterone and medroxyprogesterone acetate on pregnancy 
length and litter size in mink. Lab. Anim. Sci. 35, 156-158.

Jarosz, S., Slawon, J. \& Motz, J. (1968) Attempts to determine the relationship between sexual reflexes, semen characters and fertility in mink. Roczn. Nauk. roln. Ser. B, Zootech. 90, 463-475.

Jarosz, S., Barabasz, B. \& Szelesczuk, O. (1987) Estrusinducing trial using oil PMSG in mink. Scientifur 11, $127-128$.

Jensen, S., Kihlström, J.E., Olsson, M., Lundberg, C. \& Örberg, J. (1977) Effects of PCB and DDT on mink (Mustela vison) during the reproductive season. Ambio 4, 239.

Jergensen, G. (1985) Mink production. Scientifur, Hilleroed, Denmark, 399 pp.

Jorgensen, G., Poulsen, J.S.D. \& Bendixen, P. (1976) The influence of breeding, production and acid-base balance when mink are fed on acidified feed. Nord. VetMed. 28, 592-602.

Johansson, I. \& Venge, O. (1951) Relation of the mating interval to the occurrence of superfetation in the mink. Acta zool. (Stockh.) 32, 255-258.

Johansson, I. (1965a) Studies on the genetics of ranchbred mink. II. Fecundity, viability and body size of various color mutants. Z. Tierz. Zuchtungsbiol. 81, 55-72.

Johansson, I. (1965b) Studies on the genetics of ranchbred mink. III. Causes of variation in litter size and frequency of reproductive failures. Z. Tierz. Zuchtungsbiol. 81, 73-88.

Jones, R.E., Aulerich, R.J. \& Ringer, R.K. (1982) Feeding supplemental iodine to mink: reproductive and histopathologic effects. J. Toxicol. Environ. Health $10,459-472$.

Kangas, J. \& Mäkelä, J. (1972) The influence of feeding packing plant byproducts containing thyroids and parathyroids on the reproduction of rats and mink. Nord. VetMed. 24, 162-170.

Kangas, J. \& Mäkelä, J. (1974) Dicumarol as cause of abortion in mink. Nord. VetMed. 25, 444447.

Kellogg, C.E., Bassett, C.F. \& Enders, R.K. (1948) Mink raising. Circ. US Dept Agric. No. 801, 42 pp.

Kidnadze, I.I., Zybina, T.G., Zybina, E.V. \& Zhelezova, A.I. (1980) Characteristics of nuclear structure and karyosphere formation during the oogenesis of the mink. Tsitologiya 22, 127-133.

Kim, J.W., Ahmad, M.S. \& Kitts, W.D. (1978a) Ultrastructure of mink (Mustela vison) spermatozoa. Korean J. Anim. Sci. 20, 52-65.

Kim, J.W., Ahmad, M.S. \& Kitts, W.D. (1978b) Ultrastructural changes in mink (Mustela vison) spermatozoa during maturation. Korean J. Anim. Sci. 20, 468484.

Kim, J.W., Kitts, W.D., Ahmad, M.S. \& Krishnamurti, C.R. (1979) The ultrastructure of mink (Mustela vison) spermatozoa. Can. J. Zool. 57, 924-933.

Kirk, R.J. (1962) The effect of darkness on the mink reproductive cycle. Fur Trade J. Can. 40, 8, 15.

Kissen, A.T. \& Price, J.W. (1962) Studies on the embryology of the mink. J. Morph. 110, 105-119.

Klochkov, D.V. (1980) Effect of reduced daylight period on spermatogenesis in young mink males. Ontogenez 11, 91-95.

Klochkov, D.V. (1984) The effect of photoperiodic con- ditions on mink spermatogenesis in the prepubertal period. Sb. Khoz. Biol. 4, 31-34.

Klochkov, D.V. \& Kim, A.A. (1979) Effect of photoperiod on sexual function in male minks of different genotypes. Sb. Khoz. Biol. 14, 66-70.

Klochkov, D.V., Markel, A.L. \& Prasolov, A.I. (1982) The effect of constant light on the function of the testes and adrenals in young mink. Ontogenez 13, 517-523.

Knigge, K.M. \& Silverman, A-J. (1971) Transport capacity of the median eminence. Brain-endocrine interaction. In Median Eminence: Structure and Function, pp. 350-363. Eds K. M. Knigge, D. E. Scott \& A. Weindl. Karger, Basel.

Kolpovskii, V.M. (1978) The morphology of the ovaries of the pregnant mink (Mustela vison). Zool. Zh. 57, 1860-1869.

Kolpovskii, V.M. (1979) Postnatal changes of uterus and ovaries in mink Mustela vison (Carnivora, Mustelidae). Zool. Zh. 58, 409-418.

Kolpovskii, V.M. (1983) Dioestrus in American mink. Pushn Zverovod. Potreb. Koop. Kirov 1, 79-90.

Konrad, J., Mouka, J. \& Hanak, J. (1972) Induction of oestrus in anaphrodisiac mink females by serum gonadotropins. Vet. Med. (Praha) 17, 487-493.

Kostron, K. \& Kukla, F. (1970) Einige Morphologische Untersuchungen an Nichtranzenden Nerzrüden. Acta univ. agric. Brno 18, 725-732.

Kostron, K. \& Kukla, F. (1971) The seasonal changes of the mink's testicle volume. Acta univ. agric. Brno 19, 171-178.

Kraemer, D.C. (1983) Intra- and interspecific embryo transfer. J. exp. Zool. 228, 363-372.

Krause, D.M., Aulerich, R.J. \& Ringer, R.K. (1986) Description of the cytoplasmic droplet on mink spermatozoa. Scientifur 10, 36-39.

Krieger, M.S., Morrell, J.I. \& Pfaff, D.W. (1977) Autoradiographic localization of estradiol-concentrating cells in the female hamster brain. Neuroendocrinology 22, 193-205.

Kruska, D. (1977) On the postnatal development of the brain of the farm mink Mustela vison $\mathrm{f}$. dom. (Mustelidae; Mammalia). Z. Saugetierk. 42, 240-255.

Kukla, F. (1970) Reproductive capacity in male mink. Chovatel 9, 234-235.

Kukla, F. (1971) Effect of the duration of coitus on fertility of female mink. Chovatel 10, 232.

Kukla, F. (1975) The relationship of time of mating mink females with their fertility. Acta univ. agric. Brno 23, 145-154.

Kukla, F. (1977) The relationship of the duration of copulation with fertility of mink females. Acta univ. agric. Fac. Agron. Brno 25, 155-162.

LaFortune, J.G. \& Rheault, J.P.E. (1960) Clinical evaluation tests with reserpine (serpasil) in mink. Can. $J$. comp. Med. 24, I-9.

Larsen, A.E., Porter, D.D. \& Porter, H.G. (1971) Pregnancy-associated serum protein in mink. Proc. Soc. exp. Biol. Med. 136, 430432.

Leblond, C.P. \& Clermont, Y. (1952) A definition of the stages of the cycles of the seminiferous epithelium in the rat. Ann. N.Y. Acad. Sci. 55, 548-573.

Lecht, M. \& Reck, J. (1957) On mating methods in mink. Arch. Geflügelz. Kleintierk. 6, 156-160. 
Long, C.A. (1969) Gross morphology of the penis in seven species of the Mustelidae. Mammalia 33, 145-160.

Long, C.A. \& Shirek, L.R. (1970) Variation and correlation in the genital bones of ranch mink. Z. Saugetierk. 35, 252-255.

Lukola, A. \& Sundqvist, C. (1986) Improved sperm counts in mink males (Mustela vison) treated with clomiphene citrate. J. Endocr. Invest. 9, 243-244.

Maciejowski, J., Slawon, J. \& Brzozowski, S. (1973) Effect of different mating systems on the fertility of mink. Pr. Mater. Zootech. 4, 5568.

MacLennan, R.R. \& Bailey, E.D. (1972) Role of sexual experience in breeding behavior of male ranch mink. J. Mammal. 53, 380-382.

Martinet, L. \& Allain, D. (1985) Role of the pineal gland in the photoperiodic control of reproductive and non-reproductive functions in mink (Mustela vison). In Photoperiodism, Melatonin and the Pineal (Ciba Fdn Symp. 117), pp. 170-187. Pitman, London.

Martinet, L., Allain, D. \& Meunier, M. (1978) Photoperiodic control of plasma testosterone concentration in the mink (Mustela vison). Scientifur 2, 16-19.

Martinet, L., Allais, C. \& Allain, D. (1981a) Role of prolactin and $\mathrm{LH}$ in luteal function and blastocyst growth in mink (Mustela vison). J. Reprod. Fert., Suppl. 29, 119-130.

Martinet, L., Meunier, M. \& Allain, D. (1981b) Control of delayed implantation and onset of spring moult in the mink (Mustela vison) by daylight ratio, prolactin and melatonin. In Photoperiodism and Reproduction in Vertebrates, pp. 253-261. Eds R. Ortavant, J. Pelletier \& J. P. Ravault. INRA, Paris.

Martinet, L., Ravault, J.P. \& Meunier, M. (1982) Seasonal variations in mink (Mustela vison) plasma prolactin measured by heterologous radioimmunoassay. Gen. comp. Endocrinol. 48, 71-75.

Martinet, L., Allain, D. \& Meunier, M. (1983) Regulation in pregnant mink (Mustela vison) of plasma progesterone and prolactin concentrations and regulation of onset of the spring moult by daylight ratio and melatonin injections. Can. J. Zool. 61, 19591963.

Martinet, L., Allain, D. \& Chabi, Y. (1985) Pineal denervation by cervical sympathetic ganglionectomy suppresses the role of photoperiod on pregnancy or pseudopregnancy, body weight and moulting periods in the mink (Mustela vison). J. Endocr. 107, 31-39.

Mead, R.A. (1975) Effects of hypophysectomy on blastocyst survival, progesterone secretion and nidation in the spotted skunk. Biol. Reprod. 15, 526-532.

Mead, R.A. (1981) Delayed implantation in mustelids with special emphasis on the spotted skunk. $J$. Reprod. Fert., Suppl. 29, 11-24.

Miladinovic, Z. (1969) Morphology and vascularization of the female genital organs in mink. Acta. vet. (Belgr.) 19, 155-165.

Miljkovic, V., Zivanovic, D. \& Buric, I. (1966) Electroejaculation in the mink and some laboratory animals. Acta. vet. (Belgr.) 16, 363-371.

Mills, J. (1961) Diethylstilbestrol as a contaminant in mink feeding. Can. J. comp. Med. Vet. Sci. 25, 205 210.

Moller, O.M. (1973a) The fine structure of the ovarian interstitial gland cells in the mink, Mustela vison. $J$. Reprod. Fert. 34, 171-174.
Maller, O.M. (1973b) The progesterone concentrations in the peripheral plasma of the mink (Mustela vison). J. Endocr. 56, 121-132.

Møller, O.M. (1973c) The fine structure of the lutein cells in the mink (Mustela vison) with special reference to the secretory activity during pregnancy. Z. Zellforsch. mikrosk. Anat. 138, 523-544.

Meller, O.M. (1974) Plasma progesterone before and after ovariectomy in unmated and pregnant mink, Mustela vison. J. Reprod. Fert. 37, 367-372.

Møller, O. \& Nordstoga, K. (1978) Endotoxin-induced embryonic death in mink. Scientifur 2, 7-10.

Mondain-Monval, M., Caillol, M. \& Meunier, M. (1985) Heterologous radioimmunoassay of LH in two seasonally breeding animals: hare (Lepus europaeus) and mink (Mustela vison). Can. J. Zool. 63, 1339-1344.

Morrell, J.I., Ballin, A. \& Pfaff, D.W. (1977) Autoradiographic demonstration of the pattern of ${ }^{3} \mathrm{H}$-estradiol concentrating cells in the brain of a carnivore, the mink, Mustela vison. Anat. Rec. 189, 609-624.

Moshonkin, N.N. (1981) Potential polyestricity of the mink. Zool. Zh. 60, 1731-1733.

Muresan, E., Miclea, M., Duca, C. \& Papay, Z. (1984) Morphological study of mink ovary within 1 sexual cycle. Bull. Inst. Agron. Cluj-Napoca, Ser. Zootech. Med. Vet. 38, 61-64.

Murphy, B.D. (1976) Effects of synthetic GnRH on litter size in ranch mink bred once or twice. Theriogenology 6, 463-469.

Murphy, B.D. (1977) Effect of lengthened photoperiod after mating on litter size in mink. Scientifur 1, 16-19.

Murphy, B.D. (1979a) Effects of GnRH on plasma LH and fertility in mink. Can. J. Anim. Sci. 59, 25-33.

Murphy, B.D. (1979b) The role of prolactin in implantation and luteal maintenance in the ferret. Biol. Reprod. 21, 517-521.

Murphy, B.D. (1983a) Effects of single or multiple injections of medroxyprogesterone acetate on the reproductive performance and gestation length of ranch mink. Can. J. Anim. Sci. 63, 989-991.

Murphy, B.D. (1983b) Precocious induction of luteal activation and termination of delayed implantation in mink with the dopamine antagonist pimozide. Biol. Reprod. 29, 658-662.

Murphy, B.D. \& James, D.A. (1974a) The effects of light and sympathetic innervation to the head on nidation in mink. J. exp. Zool. 187, 267-276.

Murphy, B.D. \& James, D.A. (1974b) Mucopolysaccharide histochemistry of the mink uterus during gestation. Can. J. Zool. 52, 687-693.

Murphy, B.D. \& James, D.A. (1976) Cells of the adenohypophysis of the mink (Mustela vison) identified by immunohistochemical and functional criteria. Acta anat. 94, 184-203.

Murphy, B.D. \& Moger, W.H. (1977) Progestins of mink gestation: the effects of hypophysectomy. Endocr. Res. Commun. 4, 45-60.

Murphy, B.D., Humphrey, W.D. \& Shepstone, S.L. (1980) Luteal function in mink: The effects of hypophysectomy after the preimplantation rise in progesterone. Anim. Reprod. Sci. 3, 225-232.

Murphy, B.D., Concannon, P.W., Travis, H.F. \& Hansel, W. (1981) Prolactin: the hypophyseal factor that terminates embryonic diapause in mink. Biol. Reprod. 25, 487-491. 
Murphy, B.D., Concannon, P.W. \& Travis, H.F. (1982) Effects of medroxyprogesterone acetate on gestation in mink. J. Reprod. Fert. 66, 491-497.

Murphy, B.D., Mead, R.A. \& McKibbin, P.E. (1983) Luteal contribution to the termination of preimplantation delay in mink. Biol. Reprod. 28, 497-503.

Murphy, B.D., Rajkumar, K. \& Silversides, D.W. (1984) Luteotrophic control of the mink corpus luteum during the postimplantation phase of gestation. Proc. 3rd Int. Sci. Congr. Fur Animal Prod., Versailles, p. 32, Abstr.

Narucka, I. (1973) Effect of time and system of mating on litter size in mink. Roczn. Akad. roln. Pozn. 66, 97104.

Nemetallah, B.R., Howell, R.E. \& Ellis, L.C. (1985) Histamine and secondary autoimmune infertility in dark mink (Mustela vison). Archs Androl. 15, 79-82

Nes, N. (1965) Abnormalities of the female genital organs in mink heterozygous for the Heggedal factor (Shadow factor). Acta vet. scand. 6, 65-99.

Nieschlag, E. \& Bieniek, H. (1975) Endocrine testicular function in mink during the first year of life. Acta endocr., Copenh. 79, 375-379.

Nosova, N.G. (1977a) Effect of the progestogen megestrol acetate on the ovaries and uterus of minks during the estrus cycle. Proc. 2nd All-Union Scient. Congr., Kirov, pp. 126-127.

Nosova, N.G. (1977b) Some reasons for infertility in female mink. Nauchni Trud. nauchno-izsled. Inst. Pushn. Zverovod. Krolikovod. 15, 13-20.

Nosova, N.G. (1977c) Ovulation and the development of corpora lutea in female mink. Nauchni Trud. nauchno-izsled. Inst. Pushn. Zverovod. Krolikovod. 15, 21-32.

Nosova, N.G. (1978) Morphological and histological changes of ovaries, uterus and thyroid gland in mink given megestrol acetate. Nauchni Trud. nauchnoizsled. Inst. Pushn. Zverovod. Krolikovod. 17, 61-75.

Onstad, O. (1961 a) Hypoplasia of testes in mink. Nord. VetMed. 13, 510-516.

Onstad, O. (1961b) Aplasia of epididymis and vas deferens as a cause of sterility in mink. Nord. VetMed. 13, 543-549.

Onstad, O. (1967) Studies on postnatal testicular changes, semen quality, and anomalies of reproductive organs in the mink. Acta endocr., Copenh., Suppl. 117, 1-117.

Ortavant, R., Pelletier, J., Ravault, J.P., Thimonier, J. \& Volland-Nail, P. (1985) Photoperiod: main proximal and distal factor of the circannual cycle of reproduction in farm mammals. Oxford Rev. Reprod. Biol. 7, 305-345.

Pace, N.C., Warren, R.P. \& Ellis, L.C. (1987) A natural killer cell assay for the mink using a mouse lymphoma as the target cell line. Lab. Anim. Sci. 37, 220223.

Papke, R.L., Concannon, P.W., Travis, H.F. \& Hansel, W. (1980) Control of luteal function and implantation in the mink by prolactin. J. Anim. Sci. 50, $1102-1107$

Paul, J.R. (1968) Baculum development in mink. Trans III. Acad. Sci. 61, 308-309.

Pearson, O.P. \& Enders, R.K. (1944) Duration of pregnancy in certain Mustelids. $J$. exp. Zool. 95, 21-35.
Pekkanen, T., Lindberg, P. \& Sankari, S. (1983) The effect of colistin feeding during mating, gestation and lactation periods on whelping result in mink. Nord. VetMed. 35, 91-94.

Pelletier, R-M. (1986a) Differentiation of annulate lamellae during spermiogenesis in the mink. J. Cell Biol. 103, 83A, Abstr.

Pelletier, R-M. (1986b) Cyclic formation and decay of the blood-testis barrier in the mink (Mustela vison), a seasonal breeder. Am. J. Anat. 175, 91-117.

Pelletier, R-M. \& Shivers, R.R. (1986) Filipin-sterol complexes in breeding and nonbreeding mink (Mustela vison) Sertoli cell junctional membranes. J. Cell Biol. 103, 365A, Abstr.

Petrova, I.P., Reznikov, A.G., Kolpovskii, V.M. \& Demchenko, V.N. (1983) The content of sex steroids in the blood of pregnant American mink. Fiziol. Zh. (Kiev) 29, $434-438$.

Pilbeam, T.E., Concannon, P.W. \& Travis, H.F. (1979) The annual reproductive cycle of the mink (Mustela vison). J. Anim. Sci. 48, 578-584.

Pilleri, G. (1960) The brain of Mustela vison and Memphitis memphitis (Carnivora, Mustelidae). Rev. Suisse Zool. 67, 141-158.

Platonow, N.S. \& Karstad, L.H. (1973) Dietary effects of polychlorinated biphenyls on mink. Can. J. comp. Med. 37, 391-400.

Pomytko, V.N., Bernatskii, V.G., Kruglova, N.M. \& Dubovaya, R.G. (1972) Semen collection, dilution, storage and artificial insemination in mink. Nauchni Trud. nauchno-izsled. Inst. Pushn. Zverovod. Krolikovod. 11, 165-170.

Popov, V.A. (1943) A new age index in Mustelinae. Dokl. Akad. nauk SSSR 38, 258-260.

Prasolov, A.I. (1979) A morphometric study of the spermatogenic tubules of the mink during the period of involution and regression of the spermatogenic epithelium. Nauchni Trudy Voronezh. Lesokhim Inst. 106, 105-112.

Rauluszkiewicz, S., Senze, A. \& Nogala, M. (1971) Practical application of cytological and cytogenetic examinations of mink. Medycyna wet. 27, 302-304.

Ravault, J.P., Martinet, L., Bonnefond, C., Claustrat, B. \& Brun, J. (1986) Diurnal variations of plasma melatonin concentrations in pregnant mink (Mustela vison) maintained under different photoperiods. $J$. Pineal. Res. 3, 365-373.

Rebreanu, L., Bura, M. \& Crisan, S. (1981a) Effect of number of matings and prolificacy on gestation length in mink. Lucr. Stiint. Inst. agron. Timis. Zootech. 18, 249 253.

Rebreanu, L., Bura, M. \& Crisan, S. (1981b) Effect of light factors on gestation length in mink. Lucr. Stiint. Inst. agron. Timis. Zootech. 18, 258-263.

Reiter, R.J. (1974) Circannual reproductive rhythms in mammals related to photoperiod and pineal function: a review. Chronobiologia 1, 365-395.

Ribas, J.L. (1973) Ultrastructural study of organ-cultured rat and mink median-eminence and pars tuberalis. In Vitro 8, 439, Abstr.

Rietveld, A.A. (1978) Three years of practical application of hCG at Northwood Fur Farms Inc. Scientifur 2, 27-33.

Rietveld, A.A.M. (1982) Tolerance levels of PCB in mink feed. Scientifur 6, 35-37. 
Ringer, R.K., Aulerich, R.J. \& Bleavins, M.R. (1981) Biological effects of PCBs and PBBs on mink and ferrets - a review. In Halogenated Hydrocarbons: Health and Ecological Effects, pp. 329-343. Ed. M. A. Q. Khan. Pergamon Press, Elmsford.

Roosen-Runge, E.C. \& Giesel, L.O. (1950) Quantitative studies on spermatogenesis in the albino rat. $A m . J$. Anat. 87, 1-30.

Rose, J., Stormshak, F., Adair, J. \& Oldfield, J. (1983a) Prolactin binding sites in the uterus of the mink. Molec. cell. Endocr. 31, 131-139.

Rose, J., Stormshak, F., Adair, J. \& Oldfield, J. (1983b) Uterine progesterone metabolism in the mink during delayed implantation. Biol. Reprod. 28 (Suppl) 1, 137, Abstr.

Rose, J., Oldfield, J.E. \& Stormshak, F. (1986) Changes in serum prolactin concentrations and ovarian prolactin receptors during embryonic diapause in mink. Biol. Reprod. 34, 101-106.

Rouvet, D.M. (1982) Ultrastructure of the pineal gland of the mink (Mustela vison). Am. J. vet. Res. 43, 14921496.

Rush, G.F., Smith, J.H., Maita, K., Bleavins, M., Aulerich, R.J., Ringer, R.K. \& Hook, J.B. (1983) Perinatal hexachlorobenzene toxicity in the mink. Environ. Res. 31, 116-124.

Sakai, Y. (1981) A quantitative study on the seminiferous epithelium of the adult mink in the post-breeding season. Jpn J. vet. Res. 29, 30, Abstr.

Shackelford, R.M. (1952) Superfetation in the ranch mink. Am. Nat. 86, 311-319.

Shackelford, R.M. (1984) American mink. In Evolution of Domesticated Animals, pp. 229-234. Ed. I. L. Mason. Longman Group Ltd., London.

Shackelford, R.M. \& Cochrane, R.L. (1962) Reproductive performance of female mink fed stilbestrol. $J$. Anim. Sci. 21, $226-231$

Silverman, A-J. \& Knigge, K.M. (1972) Transport capacity of the median eminence. II. Thyroxine transport. Neuroendocrinology 10, 71-82.

Silverman, A-J. \& Knigge, K.M. (1973) Transport capacity of median eminence: III. Amino acid and thyroxine transport of organ-cultured median eminence. Neuroendocrinology 11, 107-118.

Silverman, A-J., Knigge, K.M. \& Peck, W.A. (1972) Transport capacity of median eminence. I. Amino acid transport. Neuroendocrinology 9, 123-132.

Skrede, A. (1978) Utilization of fish and animal by-products in mink nutrition. II. Effect of source and level of protein on female reproductive performance, and preweaning growth and mortality of the progeny. Acta agric. scand. 28, 130-140.

Skrivan, M., Fiedler, J. \& Siler, R. (1975) The number of sterile females in a population of standard mink. Zivočišná výroba 20, 681-686.

Stevenson, W.G. (1945) The gestation period of mink. Can. J. comp. Med. 9, 38-39.

Stevenson, W.G. (1946) The effect of sunlight on the initiation of sexual activity in ranch mink. Can. $J$. comp. Med. 10, 137-142.

Stolc, M., Fantova, M. \& Skrivan, M. (1984) Fertility of female Standard mink mated at different frequencies. Zivočišná výroba 41, 123-133.

Sundqvist, C. (1985) Morphometric studies on mink testicular tissue. Theriogenology 24, 713-723.
Sundqvist, C. (1986) Recent male mink reproduction studies and some prospects for the future. Scientifur 10, $26 \mathrm{I}-264$.

Sundqvist, C. \& Gustafsson, M. (1983) Sperm test-a useful tool in breeding work on mink. J. Sci. agric. Soc. Finl. 55, 119-131.

Sundqvist, C. \& Sundqvist, T. (1986) Some observations on semen quality in mink of different fur quality. Scientifur 10, 117-118.

Sundqvist, C., Lukola, A. \& Valtonen, M. (1984) Relationship between serum testosterone concentrations and fertility in male mink (Mustela vison). $J$. Reprod. Fert. 70, 409- 412.

Sundqvist, C., Lukola, A. \& Valtonen, M. (1985) Reproductive capacity in male mink after long distance transportation in pregnant females. Andrologia 17, 575-578.

Sundqvist, C., Toppari, J., Parvinen, M., Fagerström, R. \& Lukola, A. (1986a) Elimination of infertile male mink from breeding using sperm test, testicular palpation, testosterone test and fine-needle aspiration biopsy of the testis. Anim. Reprod. Sci. 11, 295-305.

Sundqvist, C., Lukola, A. \& Parvinen, M. (1986b) Testicular aspiration biopsy in evaluation of fertility in mink (Mustela vison). J. Reprod. Fert. 77, 531-535.

Sundqvist, C., Parvinen, M. \& Lukola, A. (1987) Aspiration biopsy of the testis-a useful tool in mink. Scientifur 11, 209-211.

Sundqvist, C., Ellis, L.C. \& Bartke, A. (1988) Reproductive endocrinology of the mink (Mustela vison). Endocr. Rev. 9, 247-266.

Svihla, A. (1931) Habits of the Louisiana mink (Mustela vison vulgivaqus). J. Mammal. 12, 366-368.

Tauson, A-H. (1985a) Different feeding intensity levels to mink. 1. Effects on male reproductive performance. Swed. J. agric. Res. 15, 77-85.

Tauson, A-H. (1985b) Effects of flushing on reproductive performance, ovulation rate, implantation rate and plasma progesterone levels in mink. Acta agric. scand. 35, 295-309.

Tauson, A-H. \& Alden, E. (1979) Feeding intensity trials with mink. Scientifur 3, 34-35.

Tauson, A-H. \& Alden, E. (1984) Pre-mating body weight changes and reproductive performance in female mink. Acta agric. scand. 34, 177-187.

Tauson, A-H. \& Alden, E. (1985) Different feeding intensity levels to mink. 2. Effects on female reproductive performance, pre-weaning kit growth and longevity of females. Swed. J. agric. Res. 15, 97-107.

Taylor, L.Z. (1968) Sonic booms 'common denominator' in Minnesota mink kit mortality. Am. Fur. Breeder 41, 20-21.

Tiba, T. (1973a) Histologische Untersuchung der Kinetik der Spermatogenese beim Mink (Mustela vison). III. Eine modifizierte Einteilung der Spermatogenesekinetik unmittelbar vor den Paarungszeiten (7. und 19. Lebensmonaten). Jpn. J. vet. Res. 21, 105-111.

Tiba, T. (1973b) Histologische Untersuchung der Kinetik der Spermatogenese beim Mink (Mustela vison). IV. Zellgemeinschaften in Samenepithel unmittelbar vor den Paarungszeiten (7. und 19. Lebensmonat). Jpn. J. vet. Res. 21, 112-123.

Tiba, T. (1973c) Histologische Untersuchung der Kinetik der Spermatogenese beim Mink (Mustela vison). V. 
Gonozyten und Gonozyten-aehnliche Zellen unmittelbar vor den Paarungszeiten (7. und 19. Lebensmonat). Jpn. J. vet. Res. 21, 125-138.

Tiba, T. (1973d) Histologische Untersuchung der Kinetik der Spermatogenese beim Mink. VI. Samenepithelwelle unmittelbar vor den Paarungszeiten (7. und 19. Lebensmonat). Jpn. J. vet. Res. 21, 139-154.

Tiba, T., Ishikawa, T. \& Murakami, A. (1968a) Histologische Untersuchung der Kinetik der Spermatogenese beim Mink. I. Samenepithelzyklus in der Paarungszeit. Jpn J. vet. Res. 16, 73-85.

Tiba, T., Ishikawa, T. \& Murakami, A. (1968b) Histologische Untersuchung der Kinetik der Spermatogenese beim Mink. II. Samenepithelwelle in der Paarungszeit. Jpn. J. vet. Res. 16, 159-181.

Tihonov, I.F. (1963) The relative size of the genitalia of female mink of different colour varieties. Uchen. Zap. Petrozavodsk Univ. 11, 62-63.

Tomson, F.N. (1987) Mink. Vet. Clin. North Am. Small. Anim. Pract. 17, 1145-1154.

Travis, H.F. \& Schaible, P.J. (1961) Effect of dietary fat levels upon reproductive performance of mink. $Q$. Bull. Mich. agric. Exp. Stn 43, 518-521.

Travis, H.F. \& Schaible, P.J. (1962) Effects of diethylstilbestrol fed periodically during gestation of female mink upon reproductive and kit performance. $A m . J$. vet. Res. 23, 359-361.

Travis, H.F. \& Pilbeam, T.E. (1980) Use of artificial light and day length to alter the life cycles of mink. $J$. Anim. Sci. 50, 1108-1112.

Travis, H.F., Bassett, C.F., Warner, R.G. \& Reineke, E.P. (1966) Some effects of feeding products high in naturally occurring thyroactive compounds upon reproduction of mink (Mustela vison). Am. J. vet. Res. 27, 815-817.

Travis, H.F., Richardson, G.V., Menear, J.R. \& Bond, J. (1968) The effects of simulated sonic booms on farmraised mink. J. Anim. Sci. 27, 1516, Abstr.

Travis, H.F., Bond, J., Wilson, R.L., Leekley, J.R. \& Menear, J.R. (1972) Effects of sonic booms on reproduction of mink. J. Anim. Sci. 35, 195, Abstr.

Travis, H.F., Bond, J., Wilson, R.L., Leekley, J.R., Menear, J.R. \& Curran, C.R. (1974) Effects of real and simulated sonic booms upon reproduction and kit survival of farm-raised mink (Mustela vison). Proc. Int. Livest. Environ. Symp., New York pp. 157169.

Travis, H.F., Pilbeam, T.E., Gardner, W.J. \& Cole, R.S. (1978) Relationship of vulvar swelling to estrus in mink. J. Anim. Sci. 46, 219-224.

Tung, K.S.K., Ellis, L.C., Teuscher, A., Meng, A., Blaustein, J.C., Kohno, S. \& Howell, R. (1981a) The black mink (Mustela vison) - a natural model of immunologic male infertility. J. exp. Med. 154, 1016-1032.

Tung, K.S.K., Teuscher, C. \& Meng, A.L. (1981b) Autoimmunity to spermatozoa and the testis. Immunol. Rev. 55, 217-255.

Tung, K.S.K., Ellis, L.C., Childs, G.V. \& Dufau, M. (1984) The dark mink: a model of male infertility. Endocrinology 114, 922-929.

Tung, K.S.K., Teuscher, C., Smith, S., Ellis, L. \& Dufau, M.L. (1985) Factors that regulate the development of testicular autoimmune diseases. Ann. N.Y. Acad. Sci. 438, $171-188$.

Vaala, S.S. \& Knigge, K.M. (1974) Transport capacity of median eminence: in vitro uptake of ${ }^{3} \mathrm{H}$-LRF. Neuroendocrinology 15, 147-157.

Vagin, Y.V. (1983) Intrauterine selection of mink embryos and factors determining its direction and intensity. Dokl. Biol. Sci. (Engl. Trans.) 283, 669-672.

Valtonen, M., Lukola, A., Sundqvist, C. \& Lohi, O. (1982) Treatment of mink males with chorionic gonadotropin. Proc. NJF Meeting on Fur Animal Prod., Alesund, Norway, 3 pp.

Valtonen, M., Blomstedt, L. \& Jokivartio, K. (1986) Effects of melatonin in mink. Scientifur 10, 83 .

Venge, O. (1956a) Experiments on forced interruption of the copulation in mink. Acta zool. (Stockh.) 37, 287304.

Venge, O. (1956b) Effect of oestrogen on reproduction in mink. Nord. VetMed. 8, 966-974.

Venge, O. (1959) Reproduction in the fox and mink. Anim. Breed. Abstr. 27, 129-145.

Venge, O. (1963) A note on induced sterility in mink. $J$. Reprod. Fert. 5, 83-86.

Venge, O. (1966) Mink in the wild. Nature, Lond. 217, 692.

Venge, O. (1968) Cyclical changes in testis and influence of additional light exposure on fertility in mink. Proc. 6th Int. Congr. Anim. Reprod. \& A.I., Paris, p. 81, Abstr.

Venge, O. (1973) Reproduction in the mink. K. vet.-og Landbohojsk. Arsskr. 1973, 95-146.

Weman, B. (1970) Cytological and experimental studies on the pars distalis of the mink Mustela vison, a light microscopic study. Acta zool. (Stockh.) 51, 183-202.

Weman, B. (1974a) Cytodifferentiation in the pars distalis of the pituitary gland in the fetal and juvenile mink, Mustela vison. Acta zool. (Stockh.) 55, 101117.

Weman, B. (1974b) Fine structure of the pars distalis of the pituitary gland in the female mink, Mustela vison. Acta zool. (Stockh.) 55, 119-136.

Weman, B. \& Nobin, A. (1973) the pars intermedia of the mink, Mustela vison. Fluorescence, light and electron microscopical studies. Z. Zellforsch. mikrosk. Anat. 143, 313-327.

Weman, B. \& Nobin, A. (1979) The pineal gland of the mink, Mustela vison; light-, fluorescence- and electron microscopical studies. Acta zool. (Stockh.) 60, 47-64.

Wenzel, U. \& Schicketanz, W. (1980) Correlation between nutritional state, breeding condition and reproduction performance of female mink. Scientifur 4 , 23-28.

Westermarck, H., Lauren, R. \& Eklund, E. (1979) The effect of methandienone on fur quality and reproduction of mink. Zentbl. VetMed. A 26, 754-764.

Wing, T.Y. \& Christensen, A.K. (1982) Morphometric studies on rat seminiferous tubules. Am. J. Anat. 165, 13-25.

Wren, C.D., Hunter, D.B., Leatherland, J.F. \& Stokes, P.M. (1987) The effects of polychlorinated biphenyls and methylmercury, singly and in combination on mink. II: Reproduction and kit development. Archs Environ. Contam. Toxicol. 16, 449-454.

Yamashita, T., Misu, M., Yamamoto, S., Terada, H. \& Ishii, Y. (1965a) Morphological studies on the sterility of the mink (Mustela vison), especially the socalled 'homos'. I. Macroscopical observations of the 
male urogenital organs. Res. Bull. Obihiro Zootech. Univ. Ser. I 4, 27-42.

Yamashita, T., Misu, M., Yamamoto, S., Terada, H., Takagi, S. \& Ishii, Y. (1965b) Morphological studies on the sterility of the mink (Mustela vison), especially the so-called 'homos'. II. Macroscopical observations of the female urogenital organs. Res. Bull. Obihiro Zootech. Univ., Ser. I 4, 137-151.

Yoshida, M. (1982) A stereological study on the testicular components of the mink in the pre- (4-month old) and post- (13-month old) breeding season. Jpn.J. vet. Res. 30, 42, Abstr.

Yurisova, M.N. \& Klochkov, D.V. (1978) The effect of photoperiodic conditions on hypothalamic-hypophyseal neurosecretory and sexual systems in the mink Mustela vison. Zh. Evol. Biokhim. Fiziol. 14, 559--565.
Yurisova, M.N., Klochkov, D.V., Yurlova, Z.N. \& Akimova, N.V. (1980) Morphofunctional characteristics of the hypothalamo-hypophyseal neurosecretory and gonadal systems in autumn and spring in mink. Izv. sib. Otdel. Akad. Nauk SSSR (Ser. Biol. Med. Nauk) pp. 77-84.

Zaleska-Freljan, K. (1976) Histological changes in the gonads of the American mink during postnatal development. Acta theriol. 21, 287-298.

Zhelezova, A.I. \& Sekirina, G.G. (1982) Culturing in vitro and transplanting embryos of the mink, Mustela vison. Dokl. Akad. Nauk SSSR 264, 715-717.

Zimmermann, H. (1981) Vitamin $B_{1}$ deficit in pregnant mink. Mschr. VetMed. 36, 508-510.

Received 9 May 1988 